\title{
The Significance of the Dysregulation of Canonical Wnt Signaling in Head and Neck Squamous Cell Carcinomas
}

\author{
Jarosław Paluszczak ${ }^{D}$ \\ Department of Pharmaceutical Biochemistry, Poznan University of Medical Sciences, ul. Swiecickiego 4, \\ 60-781 Poznan, Poland; paluszcz@ump.edu.pl; Tel.: +48-61-854-6624
}

Received: 6 February 2020; Accepted: 13 March 2020; Published: 15 March 2020

\begin{abstract}
The knowledge about the molecular alterations which are found in head and neck squamous cell carcinomas (HNSCC) has much increased in recent years. However, we are still awaiting the translation of this knowledge to new diagnostic and therapeutic options. Among the many molecular changes that are detected in head and neck cancer, the abnormalities in several signaling pathways, which regulate cell proliferation, cell death and stemness, seem to be especially promising with regard to the development of targeted therapies. Canonical Wnt signaling is a pathway engaged in the formation of head and neck tissues, however it is not active in adult somatic mucosal cells. The aim of this review paper is to bring together significant data related to the current knowledge on the mechanisms and functional significance of the dysregulation of the Wnt/ $\beta$-catenin pathway in head and neck tumors. Research evidence related to the role of Wnt signaling activation in the stimulation of cell proliferation, migration and inhibition of apoptosis in HNSCC is presented. Moreover, its role in promoting stemness traits in head and neck cancer stem-like cells is described. Evidence corroborating the hypothesis that the Wnt signaling pathway is a very promising target of novel therapeutic interventions in HNSCC is also discussed.
\end{abstract}

Keywords: head and neck cancer; Wnt signaling; $\beta$-catenin

\section{Introduction}

Head and neck squamous cell carcinoma (HNSCC), which is most frequently located in the oral cavity, lip, pharynx or larynx, is one of the most common types of cancer, comprising around $4 \%$ of new cancer cases each year. HNSCC incidence is higher in men than in women [1,2]. The development of HNSCC is strongly associated with long-term tobacco use, excessive consumption of strong alcohols or, especially in the case of oropharyngeal tumors, the infection with human papilloma virus (HPV), usually HPV type 16 or 18 [3]. Despite relatively easy access for clinical inspection, these tumors are frequently detected at a late stage, when therapeutic options are less effective in curing patients, who are then at a greater risk of the development of recurrent tumors or metastasis. Thus, the overall survival rates in this group of patients remain relatively low $(\sim 50 \%)$, especially when patients are diagnosed with advanced stages of the disease [4,5]. There is a need for novel biomarkers which could improve the clinical management of HNSCC patients, including better prognostication and disease monitoring. Moreover, the development of new therapeutic options is also necessary for the improvement of treatment outcomes. Standard surgery, radiotherapy and/or chemotherapy show limited efficacy in patients with advanced stages of the disease. The introduction of molecular targeted therapy may improve clinical response. However, the use of the antagonist of EGFR (cetuximab) showed only moderate effectiveness, which was related, in part, to the development of drug resistance [6]. The recently introduced immunotherapy using pembrolizumab, which activates $\mathrm{T}$ lymphocytes by 
blocking the interaction between PD-1 receptor and PD-L1, may be beneficial in patients with advanced, metastatic or recurrent HNSCC [7]. However, other therapeutic options are also necessary for the better clinical management of HNSCC patients. To that end, molecular alterations observed in HNSCC need to be studied in detail, in order to point to promising drug targets.

\section{Mechanisms of Wnt/ $\beta$-Catenin Pathway Activation in HNSCC}

Recent genomic analyses have shown the prevalence of genetic driver alterations in HNSCC, which most frequently affect genes associated with receptor tyrosine kinase (e.g., EGFR, MET, KIT), PI3K, p53, Notch or Hippo signaling pathways. On the other hand, genetic alterations in genes related to canonical Wnt signaling were rarely detected in HNSCC [8,9]. In contrast to colorectal cancers, which show molecular alterations driving Wnt signaling activation in around 90\% of cases [9], HNSCC were shown to lack CTNNB1 mutations and APC mutations were present infrequently [10-16]. The mutations of FAT1 tumor suppressor, which encodes a protocadherin protein that binds and inactivates $\beta$-catenin, were detected in some cases of HNSCC [17]. However, the activation of the Wnt/ $\beta$-catenin pathway in HNSCC seems to be more prevalent than it is suggested by genetic findings, due to cross-talk with other molecular alterations, which can lead to pathway cross-activation. Indeed, it has been shown that $\beta$-catenin can be activated via enhanced EGFR or PI3K signaling, which belong to the most frequently dysregulated signaling pathways in HNSCC. In this regard, elevated EGFR expression was associated with delocalized $\beta$-catenin expression [13]. In another study, the nuclear translocation of $\beta$-catenin correlated with high expression of EGFR in oral squamous cell carcinoma (OSCC) samples [18]. The stabilization of membrane-bound EGFR by preventing its endocytosis may lie behind galectin-mediated stimulation of $\mathrm{Wnt} / \beta$-catenin pathway activity [19]. Other studies have shown that galectin-3-mediated induction of the Wnt pathway resulted from Akt-dependent phosphorylation and inactivation of GSK-3 $\beta$ [20]. The treatment of OSCC cells with epidermal growth factor increased the level of phosphorylation of $\beta$-catenin at tyrosine residues, leading to its dissociation from E-cadherin and nuclear translocation. It also stimulated $\beta$-catenin-dependent reporter gene expression [18]. Additionally, in a study on the immortalization of primary oral keratinocytes, the introduction of a mutated version of TP53 (p53R(175)H missesnse mutation) led to a significant induction of a gene expression profile matching $\mathrm{Wnt} / \beta$-catenin pathway activation [21].

The central regulatory protein in the canonical Wnt pathway is $\beta$-catenin. Briefly, in unstimulated cells, cytoplasmic $\beta$-catenin undergoes proteasomal degradation, which is stimulated by its phosphorylation by the components of the destruction complex, which comprises casein kinase 1 (CK1), GSK-3 $\beta$, APC and AXIN (Figure 1). On the other hand, when extracellular Wnt ligands bind to Frizzled (FZD) and LRP receptors, they lead to the inhibition of the destruction complex, and the stabilization of cytoplasmic $\beta$-catenin, which may subsequently translocate to the nucleus. In the nucleus, $\beta$-catenin binds to TCF/LEF transcription factors and induces the expression of target genes, which regulate cell survival, proliferation, cell migration and apoptosis (Figure 2) [22]. 


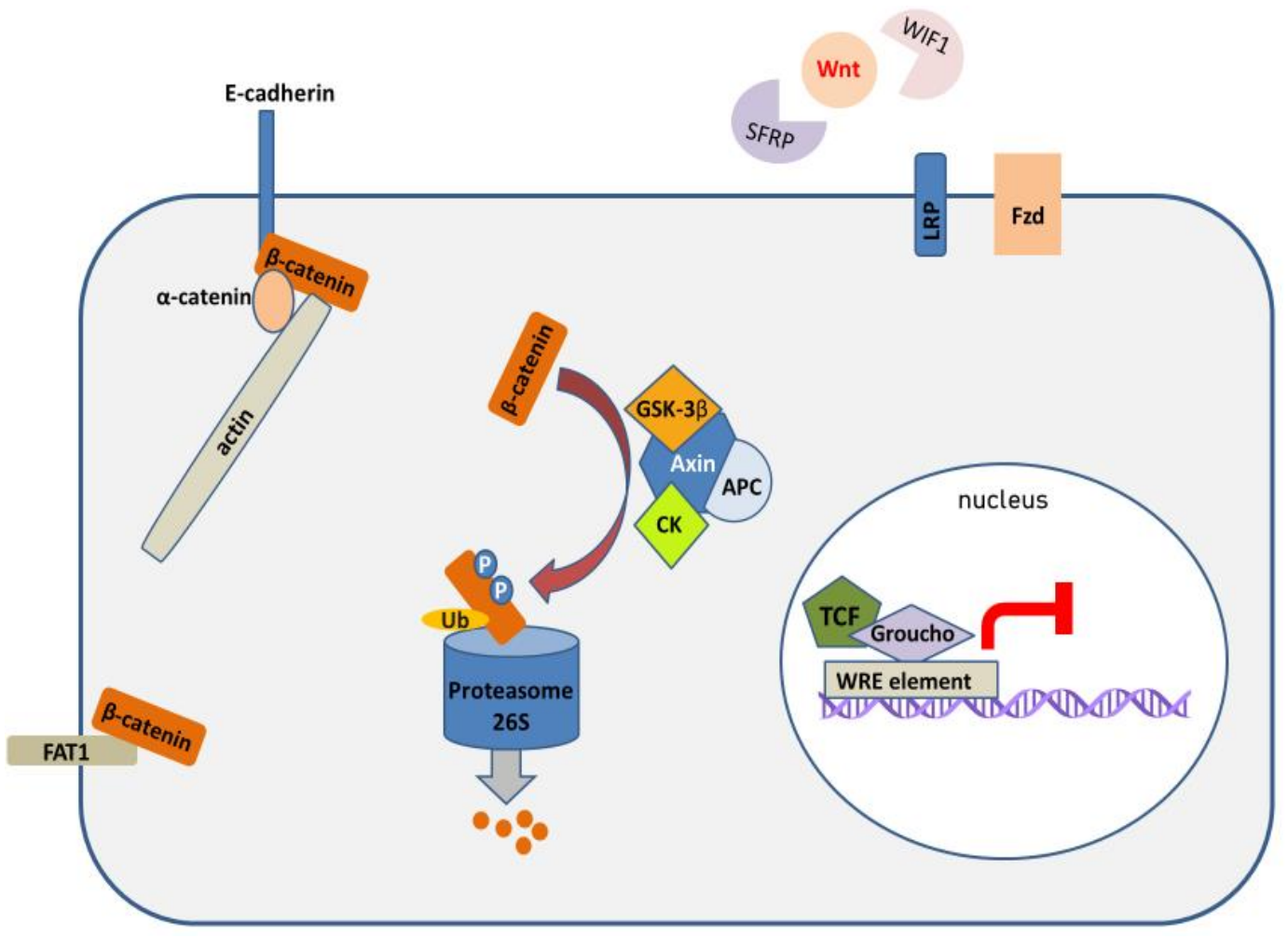

Figure 1. The fates of $\beta$-catenin, when the canonical Wnt pathway is not activated. Extracellular Wnt ligands are sequestered by antagonistic proteins (SFRPs, WIF1) and cannot bind to FZD/LRP receptors. Membrane-bound $\beta$-catenin takes part in cell-cell adhesion, together with E-cadherin and $\alpha$-catenin. Cytoplasmic $\beta$-catenin is phosphorylated by the components of the destruction complex (CK, GSK-3 $\beta$ ) and targeted for ubiquitin-mediated proteasomal degradation, and thus cannot translocate to nucleus and activate transcription. TCF/LEF transcription factors form complexes with suppressors of $\beta$-catenin-dependent transcription (e.g., Groucho) and cannot stimulate the expression of WRE-regulated genes. WRE-Wnt response element, CK-casein kinase 1.

Importantly, apart from playing a key role in Wnt signaling, $\beta$-catenin has crucial functions related to the regulation of cell-cell adhesion by the formation of adherens junctions (AJ). It forms complexes with E-cadherin, and, together with $\alpha$-catenin, takes part in associating E-cadherin to actin cytoskeleton in epithelial cells. Thus, although debatably, it is believed that there are two, relatively separate, pools of intracellular $\beta$-catenin-membranous and cytoplasmic, with distinct functions, which are regulated by partly independent mechanisms [23]. The canonical Wnt pathway is not active in normal epithelial cells of the head and neck region. Indeed, many immunohistochemical analyses have documented the membranous localization of $\beta$-catenin in cells of normal mucosal epithelium [24,25], while cytoplasmic or nuclear presence of $\beta$-catenin, which can mark canonical Wnt pathway activation, is infrequent in normal epithelial cells [26,27]. In contrast, dysplastic or cancerous epithelium shows a decrease in membranous $\beta$-catenin level and abnormal delocalization of $\beta$-catenin to cytoplasmic and, sometimes, also nuclear compartments [13,18,24,26-33]. A progressive loss of membranous $\beta$-catenin was reported during transition from hyperplasia to dysplasia and carcinoma [34]. On the other hand, some studies suggest that increased $\beta$-catenin nuclear localization is more frequent in dysplastic lesions than in tumors [35]. Elevated cytoplasmic expression of $\beta$-catenin in dysplastic oral and laryngeal lesions was associated with severity of dysplasia and increased cancer incidence [36,37]. Moreover, nuclear translocation of $\beta$-catenin was associated with severity of dysplasia [35] and increased expression of cyclin D1, c-MYC and MMP7 in oral dysplasia [26,38]. When it comes to cancer cases, the exact profile of $\beta$-catenin delocalization and expression level was related to tumor site and stage. Supraglottic tumors were characterized by stronger $\beta$-catenin delocalization than glottic tumors $[39,40]$, and lip and 
palate tumors were not characterized by significant $\beta$-catenin dysregulation [41]. The delocalization of $\beta$-catenin was more frequently observed in poorly differentiated tumors $[28,42]$. In OSCC, the intracellular expression of $\beta$-catenin was associated with the lower level of expression of involucrin, a marker of keratinocyte differentiation [43]. Moreover, the delocalization of $\beta$-catenin was frequently detected in tumor invasive front $[44,45]$. It has been confirmed that the reduction in membranous $\beta$-catenin was associated with invasive growth, higher risk of lymph node metastasis and shorter survival $[13,34,46,47]$. The higher level of cytoplasmic/nuclear $\beta$-catenin delocalization detected in the surgical margin correlated with higher recurrence rate [48]. Depending on the study, the nuclear expression of $\beta$-catenin was observed in $23 \%$ of pharyngeal tumors [49], $43 \%$ of laryngeal tumors [40], 33\% of tongue carcinomas [50], 78\% of tongue carcinomas [51] and 17\% of HPV-negative oropharyngeal carcinomas [52]. In general, the nuclear appearance of $\beta$-catenin was more frequent in poorly differentiated tumors [53]. On the other hand, some studies found only rare cases of the nuclear translocation of $\beta$-catenin in HNSCC [14,54-56].

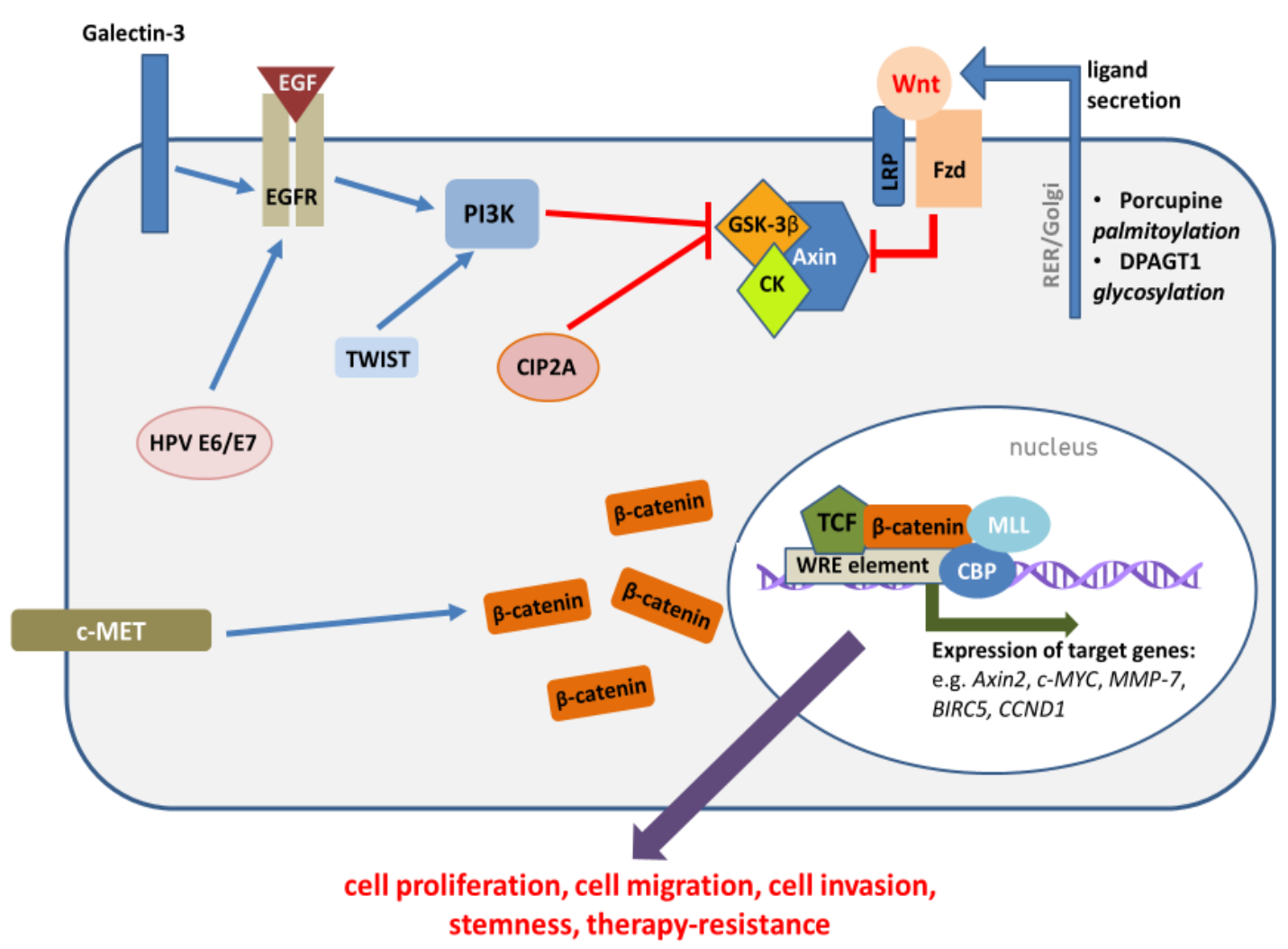

Figure 2. The activation of the canonical Wnt pathway in head and neck cancers is mediated by various factors. The synthesis of Wnt ligands is enhanced, which is related to the elevated activity of enzymes responsible for post-translational modifications-glycosylation and palmitoylation. The increased activity of Wnt ligands results from the reduced expression of extracellular Wnt antagonists. After secretion, Wnt ligands activate FZD/LRP receptors, which destabilizes the destruction complex, which can no longer phosphorylate $\beta$-catenin and stimulate its degradation. The destabilization of the destruction complex may also be mediated by the activation/overexpression of other molecular factors (e.g., EGFR, PI3K, c-MET, CIP2A), including HPV infection (details provided in the text). The resulting translocation of $\beta$-catenin to the nucleus activates TCF/LEF-mediated transcription of WRE-regulated genes, which relies on the cooperation with histone modifying proteins (MLL, CBP).

The reduction in membranous $\beta$-catenin level is frequently associated with the reduction in E-cadherin level $[51,55,57]$, which is often the consequence of the promoter methylation of the CDH1 gene $[38,58]$. The loss of E-cadherin releases $\beta$-catenin from AJ complexes, which leads to the increase 
in cytoplasmic $\beta$-catenin level and could lead to the stimulation of $\beta$-catenin transcriptional activity. However, experiments have shown that such scenario rather takes place in cells which already show canonical Wnt activation, e.g., due to destruction complex abnormalities [23]. On the other hand, activated Wnt signaling can induce the expression of DPAGT1, which encodes $N$-acetylglucosamine 1-phospho-transferase [59]. This enzyme catalyzes the rate-limiting step in protein $N$-glycosylation. Glycosylated E-cadherin shows reduced ability to form stable AJ [19]. Indeed, when E-cadherin is hypoglycosylated, the growth and migration of OSCC cells is slower. Thus, the relationship is reciprocal.

The frequently observed cytoplasmic delocalization of $\beta$-catenin cannot be considered by itself as a direct evidence of canonical Wnt pathway activation in HNSCC. However, there is also other evidence corroborating this hypothesis. The loss of membranous FAT1 is observed in poorly differentiated OSCC, and this is associated with the cytoplasmic and nuclear accumulation of $\beta$-catenin, upregulation of cell growth and loss of cell adhesion [60]. Also, the elevated expression of several Wnt ligands, which activate canonical Wnt signaling, has been detected in HNSCC. The expression of WNT-7A, $-10 \mathrm{~B}$ and -13 was higher in tumor sections than in normal mucosa [61]. Also, WNT-3A, -6 and -7 were not expressed in normal oral mucosa, but their overexpression was frequently observed in OSCC [16]. While normal human oral keratinocytes lacked WNT-7B expression, its expression was observed in oral cancers, especially in less differentiated tumors. Moreover, it correlated with lymph node invasion [62]. Oral cavity tumors expressing Wnt ligands exhibited an increased level of cytoplasmic and nuclear $\beta$-catenin, and WNT-3 expression, together with nuclear $\beta$-catenin localization, were seen predominantly at the invasive tumor front [63]. High expression of WNT-3A in laryngeal tumors was associated with lymph node metastasis and shorter survival [64]. Also, dysplastic oral lesions showed much higher WNT-3A expression than normal mucosa [26,35]. Indeed, dysplastic oral keratinocytes (DOK cell line) secrete WNT-3A, what can be inhibited by the use of C59, a Porcupine inhibitor [35]. Wnt ligands are secreted as glycolipoproteins, and abnormalities in the rate of these post-translational modifications may contribute to Wnt pathway activation. In this regard, an increased expression of DPAGT1 was observed in OSCC samples, together with an increased level of WNT-3A, which is stabilized upon glycosylation. On the other hand, the siRNA-mediated silencing of DPAGT1 was associated with a reduction in $\beta$-catenin-dependent reporter gene expression in vitro [59].

In oropharyngeal tumors, delocalized expression of $\beta$-catenin was associated with increased expression of LEF1. Importantly, LEF1 expression was absent from normal epithelium. The majority of tumors were LEF1-positive, including all advanced stage carcinomas, most recurrent cases and two thirds of tumors which were associated with death during follow-up. Interestingly, some LEF1-positive tumors were negative for $\beta$-catenin, but these tumors were positive for $\gamma$-catenin, which is redundant with $\beta$-catenin, when it comes to nuclear transcription regulation [25]. Another study found that a quarter of OSCC showed overexpression of LEF1, which was associated with poor differentiation, lymph node invasion and reduced overall survival [65]. Moreover, transcriptomic analysis of $\beta$-catenin target genes confirmed the activation of Wnt signaling in advanced and relapsed HNSCC tumors [66].

The overexpression of CIP2A, which is frequently observed in oral dysplasia and carcinoma $[67,68]$, may also contribute to the stimulation of $\beta$-catenin transcriptional activity. CIP2A acts as an antagonist of protein phosphatase PP2A complex, which functions as a cellular regulator of $\beta$-catenin by the modulation of the destruction complex. Interestingly, depending on the cellular context and the composition of PP2A subunits, PP2A may either activate or inhibit Wnt signaling [69]. Direct evidence connecting CIP2A overexpression and $\beta$-catenin nuclear translocation is currently missing. On the other hand, the expression of SET protein, which is another PP2A inhibitor, is also elevated in HNSCC [70], which suggests that the abnormalities in this system are important players during head and neck carcinogenesis. 


\subsection{The Role of Epigenetic Mechanisms in Wnt//-Catenin Pathway Activation}

Epigenetic alterations play an important role in Wnt pathway activation in HNSCC. The activity of the pathway is regulated physiologically by a series of antagonistic proteins which downregulate Wnt signaling by sequestrating extracellular Wnt ligands (SFRP and WIF proteins), blocking the receptor complex proteins (DKKs), antagonizing intracellular signal transduction (e.g., AJUBA, DAB2) or inhibiting the formation of active $\beta$-catenin transcriptional complex (e.g., Chibby). The expression of these genes is frequently reduced by promoter methylation in cancer. Indeed, SFRP1, SFRP2 and SFRP5 genes were frequently hypermethylated in OSCC cell lines and in primary tumor samples, while their ectopic expression suppressed the growth of OSCC cells in vitro [16,71]. Additionally, SFRP2 was found methylated in the majority of OSCC samples, in contrast to corresponding normal mucosa, and its overexpression reduced tumor growth in vivo [72]. It was shown that the reduction in SFRP1 and SFRP5 expression, which was induced by gene promoter methylation, was associated with cytoplasmic/nuclear delocalization of $\beta$-catenin in oral lesions [73]. Apart from SFRP1 and SFRP2, also WIF1, DKK1 and PPP2R2B were methylated in LSCC cell lines and primary tumors [74]. The expression of Wnt ligand antagonist WIF1 is observed in normal oral epithelium, suggesting that WIF1 plays a role in the inhibition of canonical Wnt signaling in healthy mucosa. However, the expression of WIF1 was much lower in OSCC samples [59], and this was related to the methylation of WIF1 promoter [73]. The methylation of WIF1 in OSCC was found to be cancer-specific when compared to normal mucosa [73,75]. The aberrant methylation of SFRP2 and WIF1 was shown to be already present in dysplastic lesions and the rate of methylation increased with progression to OSCC [76]. Another study showed that the methylation of WIF1 predicted shorter survival in OSCC patients [77], however such a correlation was not found in tongue carcinomas [78]. Also, the expression of Chibby was decreased in LSCC samples, when compared with normal laryngeal mucosa, and this was mediated by abnormal $C B Y$ promoter methylation [79].

Recent studies have shown the important involvement of regulatory RNA molecules in the regulation of $\mathrm{Wnt} / \beta$-catenin signaling, and abnormalities in the expression of miRNA were implicated in the activation of the Wnt pathway. The epigenetic silencing of miR-329 and miR-410, which may be induced by arecoline, the carcinogenic ingredient of betel quid, was associated with the upregulation of WNT-7B expression and the induction of expression of CCND1 and $c-M Y C$. It was found that arecoline leads to epigenetic silencing of these miRNAs, and the induction of their re-expression by a combined treatment with DNA methyltransferase and histone deacetylase inhibitors reduced cell proliferation and migration [62]. Also, miR-29a acts as a suppressor of canonical Wnt signaling, and it is frequently down-regulated in OSCC [80]. In contrast, miR-21 promoted the $\mathrm{Wnt} / \beta$-catenin pathway by reducing the expression of $D K K 2$, which acts as the antagonist of LRP6 co-receptor. Oral carcinomas were characterized by increased expression of miR-21 and loss of DKK2 expression [81]. Moreover, several long non-coding RNA molecules were also implicated in the regulation of Wnt signaling. The upregulation of MINCR, PLAC2 and UCA1 was frequently observed in head and neck cancers, and functionally, it promoted malignant progression by the activation of Wnt/ $\beta$-catenin pathway [82-84]. The level of MINCR expression correlated with lymph node metastasis and shorter survival of OSCC patients. The knockdown of MINCR reduced $\beta$-catenin-dependent reporter gene expression, and also reduced the expression of Wnt target genes-CCND1 and $c-M Y C$ - but elevated the level of E-cadherin. This resulted in reduced cell viability, reduced cell migration and invasion, and cell cycle arrest and increased apoptosis in cancer cell lines [82]. The elevated expression of PLAC2 in tongue carcinoma cells resulted from the enrichment of its promoter region in H3K27 acetylation, which was dependent on CBP acetyltransferase activity. PLAC2 knockdown also diminished cell proliferation and migration [83]. The overexpression of UCA1 in laryngeal cancer cells was associated with reduced GSK-3 $\beta$ phosphorylation and elevated $\beta$-catenin level. The inhibition of Wnt signaling using IWP-2, a Porcupine inhibitor, reduced the stimulatory effects of $U C A 1$ overexpression on cell proliferation and migration [84]. 


\subsection{The Role of HNSCC Etiological Factors in Wnt/3-Catenin Pathway Activation}

HNSCC is largely induced by environmental carcinogens, and it has been shown that both HPV infection and chemical carcinogens can stimulate canonical Wnt signaling in epithelial cells. Based on the analysis of the level of expression of $\beta$-catenin target genes, it has been suggested that HPV-negative tumors show stronger activation of Wnt $/ \beta$-catenin signaling, at least in patients using tobacco [85]. Also, the overexpression of ROR2, which is associated with the activation of the non-canonical Wnt pathway, was observed in HPV-positive tumors [86]. On the other hand, nuclear translocation of $\beta$-catenin was frequently observed in HPV-positive tonsillar cancers, in contrast to HPV-negative cancers, in which nuclear localization of $\beta$-catenin was more prevalent in metastases than in primary tumors [87]. Also, HPV status correlated with the loss of membranous $\beta$-catenin and the presence of nuclear $\beta$-catenin in oropharyngeal tumors $[47,88]$. It has been shown that human papillomavirus E6 and E7 oncogenes are involved in the stimulation of translocation of $\beta$-catenin to cell nucleus and the induction of $\beta$-catenin/TCF-dependent transcription of target genes, which could be reversed by E6 and E7 silencing. Mechanistically, this stimulating effect was associated with the inhibition of Siah-1-dependent $\beta$-catenin proteasomal degradation [89]. Other studies provided evidence, that HPV infection leads to $\beta$-catenin stabilization via the activation of receptor tyrosine kinase signaling. It was shown that HPV16 infection led to the phosphorylation of EGFR at Tyr 1173, which was responsible for the induction of $\beta$-catenin nuclear translocation and could be inhibited by the use of the EGFR inhibitor-erlotinib [47]. On the other hand, the sole overexpression of E6/E7 could not lead to the activation of the $\mathrm{Wnt} / \beta$-catenin pathway. However, the co-expression of E6/E7 together with ErbB-2 induced the neoplastic transformation of normal oral epithelial cells, which was associated with the downregulation of E-cadherin and the nuclear translocation of catenins [90].

4-Nitroquinoline-1-oxide (4-NQO) is a synthetic compound mimicking the action of tobacco carcinogens, and is used for the experimental induction of tongue carcinomas in rats. It leads to the progressive development of oral lesions, from hyperplasia through dysplasia to carcinoma, which show similar characteristics to human oral cancers [91]. The dysplastic lesions which developed after 4-NQO administration were characterized by cytoplasmic delocalization and nuclear translocation of $\beta$-catenin [92]. The cytoplasmic/nuclear expression of $\beta$-catenin in dysplastic and cancer cells was shown to be associated with its phosphorylation at tyrosine residues, which led to the release of $\beta$-catenin from complexes with E-cadherin [93]. It is widely recognized that the concurrent exposure to ethanol greatly potentiates the carcinogenic effects of tobacco chemicals [94]. It has been observed that the administration of 4-NQO increased the level of $\beta$-catenin in tongue epithelium, while the combined treatment with 4-NQO and ethanol additionally significantly decreased the inhibitory phosphorylation of $\beta$-catenin [95]. This suggests stronger activation of $\beta$-catenin-dependent transcription; however, this was not verified by the authors. Additionally, in a hamster model of buccal pouch carcinomas, the administration of DMBA (7,12-dimethylbenz[a]anthracene) led to a progressive increase in the level of Wnt-1, Wnt-3 and Wnt-4 ligands, and the accumulation of nuclear $\beta$-catenin. Moreover, a progressive decrease in the expression of Wif1 antagonist was observed, what could contribute to $\mathrm{Wnt} / \beta$-catenin pathway stimulation. Importantly, the expression of $\beta$-catenin target genes-Ccnd1, Mmp-2 and Mmp-9, was also elevated [96]. Finally, the neoplastic transformation of lung epithelial cells induced by cigarette smoke extract was associated with nuclear accumulation of $\beta$-catenin and a strong stimulation of $\beta$-catenin-dependent reporter gene expression. Moreover, the stimulation of $W n t / \beta$-catenin was, at least in part, dependent on the activation of Hedgehog signaling, because the transcriptional activity of $\beta$-catenin could be significantly reduced following treatment with Hedgehog pathway inhibitor cyclopamine [97].

\section{Functional Significance of Wnt/ $\beta$-Catenin Pathway Dysregulation}

It is believed that, within a tumor, cancer cells can be divided into two general groups: most cells form the bulk of tumor, and these cells are usually targeted by classical chemotherapy, while the group of tumor propagating cells, or the so called cancer stem-like cells (CSC), remain resistant to 
standard chemotherapeutics. Thus, it is currently believed that targeting CSC is the key to successful chemotherapy. Recent findings have linked abnormalities in canonical Wnt signaling to HNSCC tumor propagating cells. Indeed, higher activity of the canonical Wnt pathway correlated with stem cell traits, e.g., enhanced expression of CD44 and LGR5 [85]. LGR5 is the receptor for proteins of the R-spondin family, which synergize with Wnt ligands in the stimulation of the Wnt/ß-catenin pathway and play a role in adult stem cell regulation. The expression of LGR5 was increased in oral dysplasia and oral carcinoma [98]. On the other hand, the phenotype of cancer stem-like cells derived from HNSCC patients was associated with c-MET receptor-dependent activation of canonical Wnt signaling. c-MET was identified as a marker of self-renewal, and it induced the expression of FZD8 receptor via the activation of ERK/AP-1 signaling. The pharmacologic inhibition of c-MET eliminated cancer stem cells, and this was related to the reduction in FZD8 level and the downregulation of Wnt signaling. The c-MET inhibitor reduced the level of nuclear $\beta$-catenin and the level of $\beta$-catenin-dependent gene expression [99]. In another study, side population cells derived from HNSCC patients, which were enriched in cancer stem cells and were characterized by high invasiveness and enhanced tumorigenicity in vivo, also showed the abnormal activation of canonical Wnt signaling [100]. Laryngeal carcinoma CSC expressing CD133 were also characterized by Wnt pathway activation [101]. HNSCC cancer stem cells are frequently defined as cells expressing CD44 and ALDH1. Such population of cells was found to express nuclear $\beta$-catenin, which was associated with their self-renewal capacity, while the knockdown of $\beta$-catenin reduced stemness and tumorigenicity [102]. It has been found that Wnt activation was greatest at the boundary between epithelial and stromal compartments, and both cancer cells and cancer-associated fibroblasts mediated reciprocal stimulation by paracrine signals, mainly WNT-3A. In this model, the activation of canonical Wnt signaling induced stemness and increased invasive potential [66]. Several other studies also documented the relationship between Wnt signaling and cell invasion. WNT-1-mediated $\beta$-catenin activation was associated with reduced cell apoptosis and enhanced cell invasion in HNSCC cells [103]. The siRNA-mediated downregulation of WNT-1 expression in oral cancer cells inhibited Wnt/ $\beta$-catenin signaling and reduced the expression of Vimentin, a marker of epithelial-to-mesenchymal transition [104]. The introduction of mutated $\beta$-catenin into oral cancer cells induced the expression of Wnt target genes, including the upregulation of MMP-7, which resulted in enhanced cell migration and invasion [105]. Additionally, TRAF4-mediated activation of the Wnt/ $\beta$-catenin pathway in oral cancer cells led to increased expression of c-MYC, cyclin D1, MMP-2 and MMP-9, which was associated with enhanced cell growth and also cell migration and invasion, but it was reversed by siRNA-mediated silencing of $\beta$-catenin [106]. All this evidence suggests that targeting the Wnt/ $\beta$-catenin pathway may be utilized to significantly diminish the number of tumor propagating and invading cells, in order to prevent tumor spread or recurrence.

Many studies have analyzed the significance of therapeutic targeting of the Wnt/ $\beta$-catenin pathway in HNSCC. Due to the central role of $\beta$-catenin in mediating Wnt signal transduction and transcription activation, this protein attracted much attention when it comes to assessing the anti-cancer effects of its downregulation. The induction of $\beta$-catenin transcriptional activity in HNSCC cell lines using lithium chloride, an inhibitor of GSK-3 $\beta$, led to an increased cell proliferation rate, enhanced cell migration and invasion and a reduced rate of apoptosis [80]. Accordingly, the siRNA-mediated silencing of $\beta$-catenin in tongue cancer cells led to G0/G1 arrest, growth inhibition, decreased cell migration and increased apoptosis [51,107]. Moreover, the knockdown of CTNNB1 significantly reduced tumor growth in xenograft mice [107] and led to the induction of both apoptosis and autophagy in laryngeal cancer cells [108]. Because HNSCC cancer cells produce and secrete Wnt ligands, in contrast to normal mucosal cells, the inhibition of Wnt signaling can be affected by ligand sequestration. Indeed, antibodies against WNT-1 or WNT-10B reduced HNSCC cell viability and $\beta$-catenin-dependent reporter gene expression. Moreover, growth inhibition could be exerted with the use of recombinant SFRP1 protein [109].

Arecoline-induced $\beta$-catenin overexpression in oral epithelial cells was reduced by ERK and PI3K small molecule inhibitors [33]. It has been observed that the overexpression of TWIST1 transcription factor increased $\beta$-catenin-dependent transcription of $c-M Y C$ and $M M P-2$, which resulted in increased 
cell invasion. TWIST1-induced Wnt activation was mediated by PI3K, which phosphorylated and inactivated GSK-3 $\beta$, leading to $\beta$-catenin stabilization. Thus, TWIST1-dependent activation of $\beta$-catenin was inhibited by a PI3K inhibitor [110]. Emodin is a natural anthraquinone, which reduced TWIST1-induced epithelial-to-mesenchymal transition and invasiveness by the inhibition of the PI3K/Akt/ $\beta$-catenin pathway in hypopharyngeal cancer cells [111]. These findings underline the importance of targeting the cross-talk between PI3K/Akt and Wnt signaling in HNSCC.

The silencing of galectin- 3 in tongue cancer cells led to the induction of $\beta$-catenin degradation, which resulted in decreased level of MMP-9 expression and diminished cell migration and invasion capacity [20]. Interestingly, galectin-3-mediated cell proliferation, migration and invasion was reduced by treatment with DKK1, which suggested that the upregulation of WNT-1 expression by galectin-3 may play an important role in Wnt/ $\beta$-catenin pathway activation in galectin-3-positive cancer cells [112].

The activation of canonical Wnt signaling in HNSCC has been shown to result from the overexpression of several other proteins as well. CUL4B, which takes part in protein ubiquitination, may activate the $\mathrm{Wnt} / \beta$-catenin pathway by reducing the level of DKK1 and PPP2R2B antagonists. CUL4B was overexpressed in around 50\% of HNSCC cases. It has been shown that the knockdown of CUL4B reduced the level of active $\beta$-catenin, decreased $\beta$-catenin-dependent reporter gene transcription and led to the reduction in the level of expression of cyclicn D1, c-MYC, MMP-7 and vimentin, while it increased the level of expression of E-cadherin. It resulted in reduced cell growth and diminished cell migration and invasion. Importantly, the effects exerted by CUL4B overexpression were abolished by treatment with a tankyrase inhibitor-XAV-939, which blocks the canonical Wnt pathway by preventing AXIN degradation and subsequent destabilization of $\beta$-catenin destruction complex, which are stimulated by active tankyrase [113]. Also, glutamate decarboxylase 1 (GAD1), the key enzyme in GABA synthesis, was found to be frequently overexpressed in OSCC. It has been observed that the knockdown of GAD1 suppressed the nuclear translocation of $\beta$-catenin and reduced the level of MMP-7, which led to reduced cell migration and invasion [114]. On the other hand, the loss of expression of psoriasin, which was detected in poorly differentiated, late-stage oral cavity tumors, was associated with $\beta$-catenin activation. Psoriasin is normally engaged in the induction of GSK-3 $\beta$-independent and Siah-1-mediated degradation of $\beta$-catenin. When expressed, it reduces cell proliferation, migration and tumor growth. The downregulation of psoriasin was associated with the acquiring of cell invasiveness and tumor progression [115].

Several natural agents have been shown to exert anti-cancer effects by attenuating Wnt signaling in HNSCC. Ellagic acid prevented the formation of DMBA-induced tumors in the buccal pouch hamster model by downregulating the expression of Frizzled and Dishevelled-2 and reducing the activation of the Wnt/ $\beta$-catenin pathway [116]. Astaxanthin reduced the level of nuclear $\beta$-catenin through the inhibition of ERK/Akt kinases and reduced phosphorylation of GSK-3 $\beta$. Similar to ellagic acid, astaxanthin exerted chemo-preventive effects in the hamster buccal pouch cancer model [117]. Honokiol reduced stemness in oral cancer cells. It decreased the number of stem-like side population cells by affecting CD44 and Wnt pathway signaling. It inhibited the transcriptional activity of $\beta$-catenin and diminished the level of expression of survivin, cyclin-D1 and c-MYC, and the level of $\beta$-catenin-related epithelial-to-mesenchymal markers [118].

The inhibition of canonical Wnt signaling was also exerted by several pleiotropic therapeutics. Pyrithione zinc inhibited PI3K/Akt signaling and the downstream activation of the Wnt/ $\beta$-catenin pathway. It reduced the level of expression of c-MYC and cyclin D1. It reduced cell proliferation, migration and invasion and led to the induction of apoptosis and reduced xenograft tumor growth [119]. Nano-formulated quinacrine induced apoptosis in oral cancer stem-like cells by the joint inhibition of Wnt/ $\beta$-catenin and Hedgehog/Gli1 pathways [120]. All-trans retinoic acid is a powerful agent stimulating cell differentiation, which exerts chemo-preventive effects in head and neck carcinogenesis. Also, this compound inhibited the proliferation of head and neck cancer stem-like cells by the inhibition of $\beta$-catenin activity [121]. The antihelminthic drug niclosamide has also been shown to inhibit the Wnt pathway in head and neck cancer cells [122,123]. It led to a reduction of the level of Dishevelled-2 
and $\beta$-catenin. Also, it reduced colony formation capacity and decreased the level of expression of stemness markers in oral cancer cells [123].

Several potential molecular targets have been proposed for the effective attenuation of the Wnt $/ \beta$-catenin pathway in head and neck cancer cells [124]. Since HNSCC cells have been shown to secrete Wnt ligands, one of the strategies is to prevent the formation of mature Wnt proteins by blocking their acylation. Porcupine is a membrane-bound acyltransferase, which attaches palmitic acid residues to Wnt proteins. It has been shown that targeting Porcupine is an effective strategy of inhibition of canonical Wnt signaling in HNSCC. Small molecule inhibitors of Porcupine activity have been recently developed. LGK974 inhibited $\beta$-catenin-dependent gene expression and reduced xenograft tumor growth in mice [125]. Another Porcupine inhibitor, IWP-2, also reduced $\beta$-catenin-dependent gene expression, inhibited migration and induced apoptosis in HNSCC cells [124]. The inhibition of Porcupine by $\mathrm{C} 59$ blocked the secretion of WNT-3A by dysplastic oral keratinocytes and reduced nuclear $\beta$-catenin level, leading to the inhibition of target gene (CCND1, BIRC5) expression [35]. Moreover, Porcupine inhibitors (LGK974 and C59) impaired the initiation and growth of HPV-driven cutaneous SCC and reduced the expression of CSC markers [126].

RAP1 is another protein which enhances the nuclear translocation of $\beta$-catenin and facilitates its transcriptional activity. The silencing of RAP1 diminished the level of $\beta$-catenin activation by lithium chloride or WNT-3A. It decreased MMP-7 expression and blocked cell invasion in HNSCC cell lines [127]. This suggests that it also might serve as a molecular target for Wnt pathway inhibition. Different components of the $\beta$-catenin transcriptional complex constitute good molecular targets for Wnt inhibition. Small molecules (iCRT-3 and PKF118-310) which inhibit the interaction between $\beta$-catenin and TCF transcription factors, resulted in diminished Wnt signaling in HNSCC cells [128,129]. The activation of $\beta$-catenin-dependent transcription requires the recruitment of epigenetic writers, which modify chromatin. The CBP histone acetyltransferase is crucial in stimulating the expression of Wnt target genes. CBP inhibition reduced the expression of Wnt target genes, decreased cell migration and induced cell cycle arrest and apoptosis in HNSCC cells [124]. Moreover, its inhibition with ICG-001 led to significant anti-cancer effects-it reduced the growth of oral tumors and inhibited metastasis in vivo. Moreover, detailed analyses have shown that this compound selectively targeted cancer stem-like cell subpopulations $[130,131]$. Canonical Wnt signaling was shown to be necessary for the induction of pluripotency by the creation of permissive chromatin in stemness gene promoters. This was dependent on the formation of a complex between TCF4, $\beta$-catenin, CBP and MLL1. MLL1 is a histone methyltransferase which catalyzes H3K4 methylation. Together, these proteins were shown to interact in promoting self-renewal in HNSCC tumor propagating cells, which were highly proliferative and highly tumorigenic. The formation of this complex could be blocked by ICG-001 [130] or LF3, an inhibitor of interaction between $\beta$-catenin and TCF4 [132], which resulted in the loss of the capacity of tumor propagating cells for self-renewal and reduced tumor formation in vivo.

HNSCC tumors are frequently resistant to standard chemotherapy, and the mechanisms of chemoresistance are poorly understood. Different observations have shown that the activation of the Wnt pathway may be responsible for chemo- and radio-resistance in HNSCC, which may be contradicted with the use of Wnt pathway inhibitors. The knockdown of $\beta$-catenin sensitized HNSCC stem-like cells to cisplatin [102]. 14-3-3 $\sigma$ stabilizes GSK-3 $\beta$ and reduces TCF/LEF transcriptional activity. The downregulation of $14-3-3 \sigma$ by gene promoter methylation was responsible for the induction of cisplatin resistance in tongue cancer cells. This was mediated by the activation of the Wnt pathway [133]. In the same manner, the induction of Wnt signaling by the inhibition of GSK-3 $\beta$ using lithium chloride led to enhanced DNA repair, evasion of apoptosis and cisplatin resistance [48]. The acquired cisplatin resistance in tongue cancer cells was associated with the induction of WNT-2B and GLUT1 overexpression, and the knockdown of WNT-2B sensitized resistant cells to cisplatin treatment and reduced colony formation in vitro and tumor growth in vivo [134]. Moreover, Wnt signaling is responsible for the stimulation of DNA repair upon radiation-induced damage. In this regard, the silencing of $\beta$-catenin increased radio-sensitivity of HNSCC cells by 
preventing the induction of Ku70/Ku80 DNA repair proteins [135]. In line with this, the stimulation of $\beta$-catenin nuclear translocation led to elevated expression of $\mathrm{Ku} 70$ and $\mathrm{Ku} 80$ proteins and the induction of radio-resistance via a cyclooxygenase-2-dependent mechanism [136]. Thus, targeting Wnt signaling may be used for the sensitization of HNSCC towards chemotherapy and radiotherapy. On the other hand, the important side effects associated with radiotherapy result from the damage of irradiated normal epithelium. Interestingly, it has been shown that the activation of canonical Wnt signaling by R-spondin- 1 could contribute to the protection of normal cells from detrimental radiation-induced damage and prevent the development of oral mucositis [137]. All of the above indicate that abnormalities in $\mathrm{Wnt} / \beta$-catenin signaling consist not only of potential diagnostic markers, but, most of all, constitute promising therapeutic targets.

\section{Conclusions}

Much evidence has accumulated pointing to the significance of activated Wnt $/ \beta$-catenin signaling in driving carcinogenesis in the head and neck region. The most important molecular alterations related to Wnt pathway activation in HNSCC and promising therapeutic targets are listed in Table 1. Based on its proven connection with the induction of stemness traits, it seems that targeting the Wnt pathway may be effective in reducing cancer burden in HNSCC patients. However, several questions remain unanswered. The real extent of the activation of Wnt signaling in patients is not well characterized, thus it is not clear how to identify patients who would benefit from such molecular targeted therapy. The activation of the $\mathrm{Wnt} / \beta$-catenin pathway depends on different triggers. This would be advantageous if a model, in which these molecular triggers converge in Wnt activation, would be accurate. However, this is rather more complicated, because of the many interconnections between dysregulated molecular pathways. Thus, it would be important to analyze the head and neck cancer signalome, in order to better understand the molecular networks that drive HNSCC and how they operate in different types of cancer cells. This would allow to better define the molecular factors whose analysis could be used for the choice of drugs for precision medicine. In this context, the clinical utility of molecular therapeutics targeting Wnt signaling, especially in combination with other anti-cancer agents, needs to be precisely assessed.

Table 1. Key molecular alterations related to canonical Wnt pathway activation in HNSCC.

\begin{tabular}{ccccc}
\hline Gene/Protein & $\begin{array}{c}\text { Type of } \\
\text { Alteration }\end{array}$ & Molecular Effects & $\begin{array}{c}\text { Functional } \\
\text { Significance }\end{array}$ & Ref. \\
\hline WNT ligands & overexpression & $\begin{array}{c}\text { Dranslocation of } \\
\beta \text {-catenin }\end{array}$ & lymph node invasion & {$[61-64]$} \\
\hline APC & mutational loss & $\begin{array}{c}\text { stabilization of } \\
\beta \text {-catenin }\end{array}$ & enhanced cell growth & {$[10-16]$} \\
\hline FAT1 & mutational loss & $\begin{array}{c}\text { reduced sequestration } \\
\text { of } \beta \text {-catenin }\end{array}$ & $\begin{array}{c}\text { enhanced cell growth, } \\
\text { loss of cell adhesion }\end{array}$ & {$[60]$} \\
\hline CDH1 & (epi)mutational \\
loss & $\begin{array}{c}\text { release of } \beta \text {-catenin } \\
\text { from cell-cell junctions }\end{array}$ & $\begin{array}{c}\text { enhanced cell growth, } \\
\text { loss of cell adhesion }\end{array}$ & {$[51,55,57,58]$} \\
\hline EGFR & overexpression & $\begin{array}{c}\text { stabilization and } \\
\text { nuclear translocation } \\
\text { of } \beta \text {-catenin }\end{array}$ & $\begin{array}{c}\text { enhanced cell } \\
\text { proliferation }\end{array}$ & {$[13,18]$} \\
\hline C-MET & overexpression & $\begin{array}{c}\text { Wnt activation via } \\
\text { FZD8 }\end{array}$ & increased stemness & {$[99]$} \\
\hline SFRP1-5 & $\begin{array}{c}\text { epigenetic } \\
\text { silencing }\end{array}$ & $\begin{array}{c}\text { reduced Wnt ligand } \\
\text { sequestration }\end{array}$ & worse prognosis & {$[73]$} \\
\hline
\end{tabular}


Table 1. Cont

\begin{tabular}{|c|c|c|c|c|}
\hline Gene/Protein & $\begin{array}{l}\text { Type of } \\
\text { Alteration }\end{array}$ & Molecular Effects & $\begin{array}{l}\text { Functional } \\
\text { Significance }\end{array}$ & Ref. \\
\hline WIF-1 & $\begin{array}{l}\text { epigenetic } \\
\text { silencing }\end{array}$ & $\begin{array}{l}\text { reduced Wnt ligand } \\
\text { sequestration }\end{array}$ & worse prognosis & {$[73,77]$} \\
\hline $\begin{array}{l}\text { HPV E6/E7 } \\
\text { oncogenes }\end{array}$ & overexpression & $\begin{array}{c}\text { stabilization of } \\
\beta \text {-catenin }\end{array}$ & $\begin{array}{c}\text { neoplastic } \\
\text { transformation }\end{array}$ & {$[47,89]$} \\
\hline$\beta$-catenin & $\begin{array}{c}\text { nuclear } \\
\text { accumulation }\end{array}$ & $\begin{array}{c}\text { enhanced expression of } \\
\text { Wnt target genes } \\
(C C N D 1, c-M Y C, \\
M M P 7)\end{array}$ & $\begin{array}{c}\text { invasiveness, lymph } \\
\text { node metastasis, } \\
\text { recurrence, } \\
\text { dedifferentiation }\end{array}$ & {$[26,28,38,42,44-48]$} \\
\hline LEF1 & overexpression & $\begin{array}{l}\text { transcriptional } \\
\text { activation }\end{array}$ & lymph node invasion & {$[25,65]$} \\
\hline \multicolumn{5}{|c|}{ Targets for therapeutic inhibition of Wnt signaling } \\
\hline \multirow[t]{2}{*}{ WNT-1 } & knockdown & $\begin{array}{l}\text { reduced Vimentin } \\
\text { expression }\end{array}$ & $\begin{array}{l}\text { inhibition of } \\
\text { epithelial-to- } \\
\text { mesenchymal } \\
\text { transition }\end{array}$ & [104] \\
\hline & $\begin{array}{l}\text { inhibition by } \\
\text { antibody }\end{array}$ & $\begin{array}{l}\text { reduced expression of } \\
\text { Wnt target genes }\end{array}$ & $\begin{array}{c}\text { reduced HNSCC cell } \\
\text { viability }\end{array}$ & [109] \\
\hline $\begin{array}{l}\text { FZD-DVL } \\
\text { complex }\end{array}$ & niclosamide & altered gene expression & reduced stemness & {$[123]$} \\
\hline \multirow{4}{*}{$\beta$-catenin } & \multirow{4}{*}{ knockdown } & \multirow{4}{*}{$\begin{array}{c}\text { decreased gene } \\
\text { expression of } C C N D 1 \\
c-M Y C, M M P-7\end{array}$} & reduced stemness & [102] \\
\hline & & & $\begin{array}{l}\text { decreased cell invasion } \\
\text { cell cycle arrest, } \\
\text { reduced cell migration, } \\
\text { induction of apoptosis }\end{array}$ & $\begin{array}{c}{[106]} \\
{[51,107]}\end{array}$ \\
\hline & & & $\begin{array}{l}\text { decreased cisplatin } \\
\text { resistance }\end{array}$ & {$[102]$} \\
\hline & & & $\begin{array}{c}\text { increased } \\
\text { radiosensitivity }\end{array}$ & {$[135]$} \\
\hline \multirow[t]{3}{*}{ Porcupine } & IWP-2 inhibitor & $\begin{array}{l}\text { inhibition of UCA1- } \\
\text { dependent Wnt } \\
\text { activation }\end{array}$ & $\begin{array}{l}\text { reduced cell } \\
\text { proliferation and } \\
\text { migration }\end{array}$ & [84] \\
\hline & LGK974 inhibitor & $\begin{array}{l}\text { reduced Wnt target } \\
\text { gene expression } \\
\text { reduced secretion of }\end{array}$ & reduced tumor growth & [125] \\
\hline & C59 inhibitor & $\begin{array}{l}\text { WNT-3A, reduced } \\
\text { CCND1 and BIRC5 } \\
\text { expression }\end{array}$ & $\begin{array}{l}\text { impaired HPV-driven } \\
\text { transformation }\end{array}$ & [126] \\
\hline СBP & ICG-001 inhibitor & altered gene expression & $\begin{array}{l}\text { cell cycle arrest, } \\
\text { induction of apoptosis, } \\
\text { reduced stemness, } \\
\text { tumor growth and } \\
\text { metastasis }\end{array}$ & {$[130,131]$} \\
\hline \multirow[t]{2}{*}{ PI3K pathway } & emodin & $\begin{array}{c}\text { inhibition of PI3K/Akt/ } \\
\beta \text {-catenin pathway }\end{array}$ & $\begin{array}{l}\text { reduced cell } \\
\text { invasiveness }\end{array}$ & [111] \\
\hline & pyrithione zinc & $\begin{array}{l}\text { reduced expression of } \\
C C N D 1 \text { and } c-M Y C\end{array}$ & $\begin{array}{c}\text { reduced cell } \\
\text { proliferation and } \\
\text { invasion, apoptosis }\end{array}$ & [119] \\
\hline CUL4B & knockdown & $\begin{array}{c}\text { reduced expression of } \\
C C N D 1, c-M Y C \\
M M P-7\end{array}$ & $\begin{array}{l}\text { reduced cell growth, } \\
\text { migration and invasion }\end{array}$ & [113] \\
\hline
\end{tabular}


Funding: This work was funded by the Polish National Science Centre, grant number 2014/13/D/NZ7/00300.

Conflicts of Interest: The author declares no conflict of interest. The funder had no role in the design of the study; in the collection, analyses, or interpretation of data; in the writing of the manuscript, or in the decision to publish the results.

\section{References}

1. Ferlay, J.; Colombet, M.; Soerjomataram, I.; Mathers, C.; Parkin, D.M.; Piñeros, M.; Znaor, A.; Bray, F. Estimating the global cancer incidence and mortality in 2018: GLOBOCAN sources and methods. Int. J. Cancer 2019, 144, 1941-1953. [CrossRef]

2. Ferlay, J.; Colombet, M.; Soerjomataram, I.; Dyba, T.; Randi, G.; Bettio, M.; Gavin, A.; Visser, O.; Bray, F. Cancer incidence and mortality patterns in Europe: Estimates for 40 countries and 25 major cancers in 2018. Eur. J. Cancer. 2018, 103, 356-387. [CrossRef]

3. Szyfter, K.; Kiwerska, K.; Wierzbicka, M. HPV-related HNC-New challenge and hope for head and neck cancer subjects. J. Med. Sci. 2018, 87, 112-116. [CrossRef]

4. Gupta, B.; Johnson, N.W.; Kumar, N. Global Epidemiology of Head and Neck Cancers: A Continuing Challenge. Oncology 2016, 91, 13-23. [CrossRef]

5. Yan, K.; Agrawal, N.; Gooi, Z. Head and Neck Masses. Med. Clin. North. Am. 2018, 102, $1013-1025$. [CrossRef]

6. Braig, F.; Kriegs, M.; Voigtlaender, M.; Habel, B.; Grob, T.; Biskup, K.; Blanchard, V.; Sack, M.; Thalhammer, A.; Ben Batalla, I.; et al. Cetuximab Resistance in Head and Neck Cancer Is Mediated by EGFR-K(521) Polymorphism. Cancer Res. 2017, 77, 1188-1199. [CrossRef]

7. Sheth, S.; Weiss, J. Pembrolizumab and its use in the treatment of recurrent or metastatic head and neck cancer. Future Oncol. Lond. Engl. 2018, 14, 1547-1558. [CrossRef]

8. Iorio, F.; Knijnenburg, T.A.; Vis, D.J.; Bignell, G.R.; Menden, M.P.; Schubert, M.; Aben, N.; Gonçalves, E.; Barthorpe, S.; Lightfoot, H.; et al. A Landscape of Pharmacogenomic Interactions in Cancer. Cell 2016, 166, 740-754. [CrossRef] [PubMed]

9. Sanchez-Vega, F.; Mina, M.; Armenia, J.; Chatila, W.K.; Luna, A.; La, K.C.; Dimitriadoy, S.; Liu, D.L.; Kantheti, H.S.; Saghafinia, S.; et al. Oncogenic Signaling Pathways in The Cancer Genome Atlas. Cell 2018, 173, 321-337.e10. [CrossRef] [PubMed]

10. Yeh, K.-T.; Chang, J.-G.; Lin, T.-H.; Wang, Y.-F.; Chang, J.-Y.; Shih, M.-C.; Lin, C.-C. Correlation between protein expression and epigenetic and mutation changes of Wnt pathway-related genes in oral cancer. Int. J. Oncol. 2003, 23, 1001-1007. [CrossRef] [PubMed]

11. Tsuchiya, R.; Yamamoto, G.; Nagoshi, Y.; Aida, T.; Irie, T.; Tachikawa, T. Expression of adenomatous polyposis coli (APC) in tumorigenesis of human oral squamous cell carcinoma. Oral Oncol. 2004, 40, 932-940. [CrossRef] [PubMed]

12. Iwai, S.; Katagiri, W.; Kong, C.; Amekawa, S.; Nakazawa, M.; Yura, Y. Mutations of the APC, beta-catenin, and axin 1 genes and cytoplasmic accumulation of beta-catenin in oral squamous cell carcinoma. J. Cancer Res. Clin. Oncol. 2005, 131, 773-782. [CrossRef] [PubMed]

13. Odajima, T.; Sasaki, Y.; Tanaka, N.; Kato-Mori, Y.; Asanuma, H.; Ikeda, T.; Satoh, M.; Hiratsuka, H.; Tokino, T.; Sawada, N. Abnormal $\beta$-catenin expression in oral cancer with no gene mutation: Correlation with expression of cyclin D1 and epidermal growth factor receptor, Ki-67 labeling index, and clinicopathological features. Hum. Pathol. 2005, 36, 234-241. [CrossRef] [PubMed]

14. Yu, Z.; Weinberger, P.M.; Provost, E.; Haffty, B.G.; Sasaki, C.; Joe, J.; Camp, R.L.; Rimm, D.L.; Psyrri, A. B-Catenin Functions Mainly as an Adhesion Molecule in Patients with Squamous Cell Cancer of the Head and Neck. Clin. Cancer Res. 2005, 11, 2471-2477. [CrossRef] [PubMed]

15. Lea, I.A.; Jackson, M.A.; Li, X.; Bailey, S.; Peddada, S.D.; Dunnick, J.K. Genetic pathways and mutation profiles of human cancers: Site- and exposure-specific patterns. Carcinogenesis 2007, 28, 1851-1858. [CrossRef]

16. Sogabe, Y.; Suzuki, H.; Toyota, M.; Ogi, K.; Imai, T.; Nojima, M.; Sasaki, Y.; Hiratsuka, H.; Tokino, T. Epigenetic inactivation of SFRP genes in oral squamous cell carcinoma. Int. J. Oncol. 2008, 32, 1253-1261. [CrossRef]

17. Morris, L.G.T.; Kaufman, A.M.; Gong, Y.; Ramaswami, D.; Walsh, L.A.; Turcan, Ş.; Eng, S.; Kannan, K.; Zou, Y.; Peng, L.; et al. Recurrent somatic mutation of FAT1 in multiple human cancers leads to aberrant Wnt activation. Nat. Genet. 2013, 45, 253-261. [CrossRef] 
18. Lee, C.-H.; Hung, H.-W.; Hung, P.-H.; Shieh, Y.-S. Epidermal growth factor receptor regulates $\beta$-catenin location, stability, and transcriptional activity in oral cancer. Mol. Cancer 2010, 9, 64. [CrossRef]

19. Varelas, X.; Bouchie, M.P.; Kukuruzinska, M.A. Protein N-glycosylation in oral cancer: Dysregulated cellular networks among DPAGT1, E-cadherin adhesion and canonical Wnt signaling. Glycobiology 2014, 24, 579-591. [CrossRef]

20. Zhang, D.; Chen, Z.; Liu, S.; Dong, Z.; Dalin, M.; Bao, S.; Hu, Y.; Wei, F. Galectin-3 gene silencing inhibits migration and invasion of human tongue cancer cells in vitro via downregulating $\beta$-catenin. Acta Pharmacol. Sin. 2013, 34, 176-184. [CrossRef]

21. Smeets, S.J.; van der Plas, M.; Schaaij-Visser, T.B.M.; van Veen, E.A.M.; van Meerloo, J.; Braakhuis, B.J.M.; Steenbergen, R.D.M.; Brakenhoff, R.H. Immortalization of oral keratinocytes by functional inactivation of the p53 and pRb pathways. Int. J. Cancer 2011, 128, 1596-1605. [CrossRef] [PubMed]

22. Kleszcz, R. The canonical Wnt pathway-Functional structure and importance for head and neck squamous cell carcinomas. Postępy Biochem. 2019, 65, 183-192. [CrossRef] [PubMed]

23. Heuberger, J.; Birchmeier, W. Interplay of Cadherin-Mediated Cell Adhesion and Canonical Wnt Signaling. Cold Spring Harb. Perspect. Biol. 2010, 2, a002915. [CrossRef] [PubMed]

24. de Silva, B.S.F.; de Castro, C.A.; Von Zeidler, S.L.V.; de Sousa, S.C.O.M.; Batista, A.C. Altered $\beta$-catenin expression in oral mucosal dysplasia: A comparative study. J. Appl. Oral Sci. 2015, 23, 472-478. [CrossRef] [PubMed]

25. Papagerakis, P.; Pannone, G.; Shabana, A.-H.; Depondt, J.; Santoro, A.; Ghirtis, K.; Berdal, A.; Papagerakis, S. Aberrant $\beta$-Catenin and Lef1 Expression May Predict the Clinical Outcome for Patients with Oropharyngeal Cancer. Int. J. Immunopathol. Pharmacol. 2012, 25, 135-146. [CrossRef] [PubMed]

26. Ishida, K.; Ito, S.; Wada, N.; Deguchi, H.; Hata, T.; Hosoda, M.; Nohno, T. Nuclear localization of beta-catenin involved in precancerous change in oral leukoplakia. Mol. Cancer 2007, 6, 62. [CrossRef]

27. Cai, Z.; Shi, X.; Gao, Y.; Wei, M.; Wang, C.; Yu, G. $\beta$-catenin expression pattern in primary oral squamous cell carcinoma. Chin. Med. J. (Engl.) 2008, 121, 1866-1870. [CrossRef]

28. Williams, H.K.; Sanders, D.S.A.; Jankowski, J.A.Z.; Landini, G.; Brown, A.M.S. Expression of cadherins and catenins in oral epithelial dysplasia and squamous cell carcinoma. J. Oral Pathol. Med. 2007, 27, 308-317. [CrossRef]

29. Muzio, L.L.; Russo, L.L.; Falaschini, S.; Ciavarella, D.; Pentenero, M.; Arduino, P.; Favia, G.; Maiorano, E.; Rubini, C.; Pieramici, T.; et al. $\beta$ - and $\gamma$-catenin expression in oral dysplasia. Oral Oncol. 2009, 45, 501-504. [CrossRef]

30. Chaw, S.Y.; Abdul Majeed, A.; Dalley, A.J.; Chan, A.; Stein, S.; Farah, C.S. Epithelial to mesenchymal transition (EMT) biomarkers-E-cadherin, beta-catenin, APC and Vimentin-In oral squamous cell carcinogenesis and transformation. Oral Oncol. 2012, 48, 997-1006. [CrossRef]

31. Sasaya, K.; Sudo, H.; Maeda, G.; Kawashiri, S.; Imai, K. Concomitant Loss of p120-Catenin and $\beta$-Catenin Membrane Expression and Oral Carcinoma Progression with E-Cadherin Reduction. PLoS ONE 2013, 8, e69777. [CrossRef] [PubMed]

32. Pectasides, E.; Rampias, T.; Sasaki, C.; Perisanidis, C.; Kouloulias, V.; Burtness, B.; Zaramboukas, T.; Rimm, D.; Fountzilas, G.; Psyrri, A. Markers of Epithelial to Mesenchymal Transition in Association with Survival in Head and Neck Squamous Cell Carcinoma (HNSCC). PLoS ONE 2014, 9, e94273. [CrossRef] [PubMed]

33. Lee, S.-S.; Tsai, C.-H.; Tsai, L.-L.; Chou, M.-C.; Chou, M.-Y.; Chang, Y.-C. $\beta$-catenin expression in areca quid chewing-associated oral squamous cell carcinomas and upregulated by arecoline in human oral epithelial cells. J. Formos. Med. Assoc. 2012, 111, 194-200. [CrossRef] [PubMed]

34. Kaur, J.; Sawhney, M.; DattaGupta, S.; Shukla, N.K.; Srivastava, A.; Walfish, P.G.; Ralhan, R. Clinical Significance of Altered Expression of $\beta$-Catenin and E-Cadherin in Oral Dysplasia and Cancer: Potential Link with ALCAM Expression. PLoS ONE 2013, 8, e67361. [CrossRef]

35. Reyes, M.; Peña-Oyarzun, D.; Maturana, A.; Torres, V.A. Nuclear localization of $\beta$-catenin and expression of target genes are associated with increased Wnt secretion in oral dysplasia. Oral Oncol. 2019, 94, 58-67. [CrossRef]

36. Álvarez-Marcos, C.; López, F.; Alonso-Guervós, M.; Domínguez, F.; Suárez, C.; Hermsen, M.A.; Llorente, J.L. Genetic and protein markers related to laryngeal epithelial precursor lesions and their neoplastic progression. Acta Otolaryngol. (Stockh.) 2013, 133, 281-290. [CrossRef] 
37. López, F.; Álvarez-Marcos, C.; Alonso-Guervós, M.; Domínguez, F.; Suárez, C.; Hermsen, M.A.; Llorente, J.L. From laryngeal epithelial precursor lesions to squamous carcinoma of the larynx: The role of cell cycle proteins and $\beta$-catenin. Eur. Arch. Otorhinolaryngol. 2013, 270, 3153-3162. [CrossRef]

38. Alvarado, C.G.; Maruyama, S.; Cheng, J.; Ida-Yonemochi, H.; Kobayashi, T.; Yamazaki, M.; Takagi, R.; Saku, T. Nuclear translocation of $\beta$-catenin synchronized with loss of E-cadherin in oral epithelial dysplasia with a characteristic two-phase appearance. Histopathology 2011, 59, 283-291. [CrossRef]

39. Galera-Ruiz, H.; Ríos-Moreno, M.J.; González-Cámpora, R.; Ortega, I.; Fernández, A.; García-Escudero, A.; Galera-Davidson, H. The cadherin-catenin complex in laryngeal squamous cell carcinoma. Eur. Arch. Otorhinolaryngol. 2012, 269, 1183-1188. [CrossRef]

40. Goulioumis, A.K.; Varakis, J.; Goumas, P.; Papadaki, H. Differential $\beta$-catenin expression between glottic and supraglottic laryngeal carcinoma. Eur. Arch. Otorhinolaryngol. 2010, 267, 1573-1578. [CrossRef]

41. Santoro, A.; Pannone, G.; Papagerakis, S.; McGuff, H.S.; Cafarelli, B.; Lepore, S.; De Maria, S.; Rubini, C.; Mattoni, M.; Staibano, S.; et al. Beta-Catenin and Epithelial Tumors: A Study Based on 374 Oropharyngeal Cancers. BioMed Res. Int. 2014, 2014, 1-13. [CrossRef] [PubMed]

42. Laxmidevi, L.B.; Angadi, P.V.; Pillai, R.K.; Chandreshekar, C. Aberrant $\beta$-catenin expression in the histologic differentiation of oral squamous cell carcinoma and verrucous carcinoma: An immunohistochemical study. J. Oral Sci. 2010, 52, 633-640. [CrossRef] [PubMed]

43. Ravindran, G.; Sawant, S.S.; Hague, A.; Kingsley, K.; Devaraj, H. Association of differential $\beta$-catenin expression with Oct-4 and Nanog in oral squamous cell carcinoma and their correlation with clinicopathological factors and prognosis: Association of $\beta$-catenin, with Oct- 4 and NANOG in OSCC. Head Neck 2015, 37, 982-993. [CrossRef] [PubMed]

44. Mahomed, F.; Altini, M.; Meer, S. Altered E-cadherin/ $\beta$-catenin expression in oral squamous carcinoma with and without nodal metastasis. Oral Dis. 2007, 13, 386-392. [CrossRef] [PubMed]

45. Liu, L.-K.; Jiang, X.-Y.; Zhou, X.-X.; Wang, D.-M.; Song, X.-L.; Jiang, H.-B. Upregulation of vimentin and aberrant expression of E-cadherin/ $\beta$-catenin complex in oral squamous cell carcinomas: Correlation with the clinicopathological features and patient outcome. Mod. Pathol. 2010, 23, 213-224. [CrossRef] [PubMed]

46. Ueda, G.; Sunakawa, H.; Nakamori, K.; Shinya, T.; Tsuhako, W.; Tamura, Y.; Kosugi, T.; Sato, N.; Ogi, K.; Hiratsuka, H. Aberrant expression of $\beta$ - and $\gamma$-catenin is an independent prognostic marker in oral squamous cell carcinoma. Int. J. Oral Maxillofac. Surg. 2006, 35, 356-361. [CrossRef] [PubMed]

47. Hu, Z.; Müller, S.; Qian, G.; Xu, J.; Kim, S.; Chen, Z.; Jiang, N.; Wang, D.; Zhang, H.; Saba, N.F.; et al. Human papillomavirus 16 oncoprotein regulates the translocation of $\beta$-catenin via the activation of epidermal growth factor receptor: HPV Inducing $\beta$-Catenin Translocation. Cancer 2015, 121, 214-225. [CrossRef]

48. Roy, S.; Kar, M.; Roy, S.; Saha, A.; Padhi, S.; Banerjee, B. Role of $\beta$-catenin in cisplatin resistance, relapse and prognosis of head and neck squamous cell carcinoma. Cell. Oncol. 2018, 41, 185-200. [CrossRef]

49. Pukkila, M.J.; Virtaniemi, J.A.; Kumpulainen, E.J.; Pirinen, R.T.; Johansson, R.T.; Valtonen, H.J.; Juhola, M.T.; Kosma, V.M. Nuclear beta catenin expression is related to unfavourable outcome in oropharyngeal and hypopharyngeal squamous cell carcinoma. J. Clin. Pathol. 2001, 54, 42-47. [CrossRef]

50. Lopes, F.F.; da Costa Miguel, M.C.; Pereira, A.L.A.; da Cruz, M.C.F.N.; de Almeida Freitas, R.; Pinto, L.P.; de Souza, L.B. Changes in immunoexpression of E-cadherin and $\beta$-catenin in oral squamous cell carcinoma with and without nodal metastasis. Ann. Diagn. Pathol. 2009, 13, 22-29. [CrossRef]

51. Li, S.; Jiao, J.; Lu, Z.; Zhang, M. An essential role for N-cadherin and $\beta$-catenin for progression in tongue squamous cell carcinoma and their effect on invasion and metastasis of Tca8113 tongue cancer cells. Oncol. Rep. 2009, 21, 1223-1233. [PubMed]

52. García-Pedrero, J.M.; García-Cabo, P.; Ángeles Villaronga, M.; Hermida-Prado, F.; Granda-Díaz, R.; Allonca, E.; Rodrigo, J.P. Prognostic significance of E-cadherin and $\beta$-catenin expression in HPV-negative oropharyngeal squamous cell carcinomas. Head Neck 2017, 39, 2293-2300. [CrossRef] [PubMed]

53. Zaid, K.W. Immunohistochemical Assessment of E-cadherin and $\beta$-catenin in the Histological Differentiations of Oral Squamous Cell Carcinoma. Asian Pac. J. Cancer Prev. 2014, 15, 8847-8853. [CrossRef] [PubMed]

54. Gasparoni, A.; Chaves, A.; Fonzi, L.; Johnson, G.K.; Schneider, G.B.; Squier, C.A. Subcellular localization of beta-catenin in malignant cell lines and squamous cell carcinomas of the oral cavity. J. Oral Pathol. Med. 2002, 31, 385-394. [CrossRef] [PubMed] 
55. Rosado, P.; Lequerica-Fernández, P.; Fernández, S.; Allonca, E.; Villallaín, L.; de Vicente, J.C. E-cadherin and $\beta$-catenin expression in well-differentiated and moderately-differentiated oral squamous cell carcinoma: Relations with clinical variables. Br. J. Oral Maxillofac. Surg. 2013, 51, 149-156. [CrossRef] [PubMed]

56. Fujii, M.; Katase, N.; Lefeuvre, M.; Gunduz, M.; Buery, R.R.; Tamamura, R.; Tsujigiwa, H.; Nagatsuka, H. Dickkopf (Dkk)-3 and $\beta$-catenin expressions increased in the transition from normal oral mucosal to oral squamous cell carcinoma. J. Mol. Histol. 2011, 42, 499-504. [CrossRef] [PubMed]

57. Andrews, N.; Jones, A.; Helliwell, T.; Kinsella, A. Expression of the E-cadherin-catenin cell adhesion complex in primary squamous cell carcinomas of the head and neck and their nodal metastases. Br. J. Cancer 1997, 75, 1474-1480. [CrossRef]

58. Kudo, Y.; Kitahima, S.; Ogawa, I.; Hiraoka, M.; Sargolzaei, S.; Keikhaee, M.R.; Sato, S.; Miyauchi, M.; Takata, T. Invasion and Metastasis of Oral Cancer Cells Require Methylation of E-Cadherin and/or Degradation of Membranous Beta-Catenin. Clin. Cancer Res. 2004, 10, 5455-5463. [CrossRef]

59. Jamal, B.; Sengupta, P.K.; Gao, Z.; Nita-Lazar, M.; Amin, B.; Jalisi, S.; Bouchie, M.P.; Kukuruzinska, M.A. Aberrant amplification of the crosstalk between canonical Wnt signaling and N-glycosylation gene DPAGT1 promotes oral cancer. Oral Oncol. 2012, 48, 523-529. [CrossRef]

60. Nishikawa, Y.; Miyazaki, T.; Nkashiro, K.-I.; Yamagata, H.; Isokane, M.; Goda, H.; Tanaka, H.; Oka, R.; Hamakawa, H. Human FAT1 cadherin controls cell migration and invasion of oral squamous cell carcinoma through the localization of $\beta$-catenin. Oncol. Rep. 2011, 26, 587-592.

61. Díaz Prado, S.M.; Medina Villaamil, V.; Aparicio Gallego, G.; Blanco Calvo, M.; López Cedrún, J.L.; Sironvalle Soliva, S.; Valladares Ayerbes, M.; García Campelo, R.; Antón Aparicio, L.M. Expression of Wnt gene family and frizzled receptors in head and neck squamous cell carcinomas. Virchows Arch. 2009, 455, 67-75. [CrossRef] [PubMed]

62. Shiah, S.-G.; Hsiao, J.-R.; Chang, W.-M.; Chen, Y.-W.; Jin, Y.-T.; Wong, T.-Y.; Huang, J.-S.; Tsai, S.-T.; Hsu, Y.-M.; Chou, S.-T.; et al. Downregulated miR329 and miR410 Promote the Proliferation and Invasion of Oral Squamous Cell Carcinoma by Targeting Wnt-7b. Cancer Res. 2014, 74, 7560-7572. [CrossRef] [PubMed]

63. Uraguchi, M.; Morikawa, M.; Shirakawa, M.; Sanada, K.; Imai, K. Activation of WNT Family Expression and Signaling in Squamous Cell Carcinomas of the Oral Cavity. J. Dent. Res. 2004, 83, 327-332. [CrossRef] [PubMed]

64. Zhang, D.; Li, G.; Chen, X.; Jing, Q.; Liu, C.; Lu, S.; Huang, D.; Wang, Y.; Tan, P.; Chen, J.; et al. Wnt3a protein overexpression predicts worse overall survival in laryngeal squamous cell carcinoma. J. Cancer 2019, 10, 4633-4638. [CrossRef]

65. Su, M.-C.; Chen, C.-T.; Huang, F.-I.; Chen, Y.-L.; Jeng, Y.-M.; Lin, C.-Y. Expression of LEF1 is an independent prognostic factor for patients with oral squamous cell carcinoma. J. Formos. Med. Assoc. 2014, 113, 934-939. [CrossRef]

66. Le, P.N.; Keysar, S.B.; Miller, B.; Eagles, J.R.; Chimed, T.-S.; Reisinger, J.; Gomez, K.E.; Nieto, C.; Jackson, B.C.; Somerset, H.L.; et al. Wnt signaling dynamics in head and neck squamous cell cancer tumor-stroma interactions. Mol. Carcinog. 2019, 58, 398-410. [CrossRef]

67. Katz, J.; Jakymiw, A.; Ducksworth, M.K.; Stewart, C.M.; Bhattacharyya, I.; Cha, S.; Chan, E.K.L. CIP2A expression and localization in oral carcinoma and dysplasia. Cancer Biol. Ther. 2010, 10, 694-699. [CrossRef]

68. Böckelman, C.; Hagström, J.; Mäkinen, L.K.; Keski-Säntti, H.; Häyry, V.; Lundin, J.; Atula, T.; Ristimäki, A.; Haglund, C. High CIP2A immunoreactivity is an independent prognostic indicator in early-stage tongue cancer. Br. J. Cancer 2011, 104, 1890-1895. [CrossRef]

69. Thompson, J.; Williams, C. Protein Phosphatase 2A in the Regulation of Wnt Signaling, Stem Cells, and Cancer. Genes 2018, 9, 121. [CrossRef]

70. Leopoldino, A.M.; Squarize, C.H.; Garcia, C.B.; Almeida, L.O.; Pestana, C.R.; Sobral, L.M.; Uyemura, S.A.; Tajara, E.H.; Silvio Gutkind, J.; Curti, C. SET protein accumulates in HNSCC and contributes to cell survival: Antioxidant defense, Akt phosphorylation and AVOs acidification. Oral Oncol. 2012, 48, 1106-1113. [CrossRef]

71. Marsit, C.J.; McClean, M.D.; Furniss, C.S.; Kelsey, K.T. Epigenetic inactivation of the SFRP genes is associated with drinking, smoking and HPV in head and neck squamous cell carcinoma. Int. J. Cancer 2006, 119, 1761-1766. [CrossRef] [PubMed] 
72. Xiao, C.; Wang, L.; Zhu, L.; Zhang, C.; Zhou, J. Secreted frizzled-related protein 2 is epigenetically silenced and functions as a tumor suppressor in oral squamous cell carcinoma. Mol. Med. Rep. 2014, 10, 2293-2298. [CrossRef] [PubMed]

73. Zhou, S.; Chen, L.; Mashrah, M.; Zhu, Y.; Liu, J.; Yang, X.; He, Z.; Wang, L.; Xiang, T.; Yao, Z.; et al. Deregulation of secreted frizzled-related proteins is associated with aberrant $\beta$-catenin activation in the carcinogenesis of oral submucous fibrosis. OncoTargets Ther. 2015, 2923. [CrossRef] [PubMed]

74. Paluszczak, J.; Hemmerling, D.; Kostrzewska-Poczekaj, M.; Jarmuż-Szymczak, M.; Grenman, R.; Wierzbicka, M.; Baer-Dubowska, W. Frequent hypermethylation of WNT pathway genes in laryngeal squamous cell carcinomas. J. Oral Pathol. Med. 2014, 43, 652-657. [CrossRef]

75. Pannone, G.; Bufo, P.; Santoro, A.; Franco, R.; Aquino, G.; Longo, F.; Botti, G.; Serpico, R.; Cafarelli, B.; Abbruzzese, A.; et al. WNT pathway in oral cancer: Epigenetic inactivation of WNT-inhibitors. Oncol. Rep. 2010, 24, 1035-1041.

76. Towle, R.; Truong, D.; Hogg, K.; Robinson, W.P.; Poh, C.F.; Garnis, C. Global analysis of DNA methylation changes during progression of oral cancer. Oral Oncol. 2013, 49, 1033-1042. [CrossRef]

77. Paluszczak, J.; Sarbak, J.; Kostrzewska-Poczekaj, M.; Kiwerska, K.; Jarmuż-Szymczak, M.; Grenman, R.; Mielcarek-Kuchta, D.; Baer-Dubowska, W. The negative regulators of Wnt pathway-DACH1, DKK1, and WIF1 are methylated in oral and oropharyngeal cancer and WIF1 methylation predicts shorter survival. Tumor Biol. 2015, 36, 2855-2861. [CrossRef]

78. Supic, G.; Kozomara, R.; Jovic, N.; Zeljic, K.; Magic, Z. Hypermethylation of RUNX3 but not WIF1 gene and its association with stage and nodal status of tongue cancers. Oral Dis. 2011, 17, 794-800. [CrossRef]

79. Ren, G.; Zhao, D.; Xu, J.; Li, B. Expression of CBY and Methylation of CBY at Promoter Region in Human Laryngeal Squamous Cell Carcinoma. Tumori J. 2015, 101, 215-222. [CrossRef]

80. Huang, C.; Wang, L.; Song, H.; Wu, C. MiR-29a inhibits the progression of oral squamous cell carcinoma by targeting Wnt/ $\beta$-catenin signalling pathway. Artif. Cells Nanomed. Biotechnol. 2019, 47, 3037-3042. [CrossRef]

81. Kawakita, A.; Yanamoto, S.; Yamada, S.; Naruse, T.; Takahashi, H.; Kawasaki, G.; Umeda, M. MicroRNA-21 Promotes Oral Cancer Invasion via the Wnt/ß-Catenin Pathway by Targeting DKK2. Pathol. Oncol. Res. 2014, 20, 253-261. [CrossRef]

82. Lyu, Q.; Jin, L.; Yang, X.; Zhang, F. LncRNA MINCR activates Wnt/ $\beta$-catenin signals to promote cell proliferation and migration in oral squamous cell carcinoma. Pathol. Res. Pract. 2019, 215, 924-930. [CrossRef]

83. Chen, F.; Qi, S.; Zhang, X.; Wu, J.; Yang, X.; Wang, R. lncRNA PLAC2 activated by H3K27 acetylation promotes cell proliferation and invasion via the activation of $\mathrm{Wnt} / \beta$-catenin pathway in oral squamous cell carcinoma. Int. J. Oncol. 2019, 54, 1183-1194. [CrossRef] [PubMed]

84. Sun, S.; Gong, C.; Yuan, K. LncRNA UCA1 promotes cell proliferation, invasion and migration of laryngeal squamous cell carcinoma cells by activating Wnt/ $\beta$-catenin signaling pathway. Exp. Ther. Med. 2019, 17, 1182-1189. [CrossRef] [PubMed]

85. Lepore, S.; Lettini, G.; Condelli, V.; Sisinni, L.; Piscazzi, A.; Simeon, V.; Zoppoli, P.; Pedicillo, M.C.; Natalicchio, M.I.; Pietrafesa, M.; et al. Comparative Gene Expression Profiling of Tobacco-Associated HPV-Positive versus Negative Oral Squamous Carcinoma Cell Lines. Int. J. Med. Sci. 2020, 17, $112-124$. [CrossRef] [PubMed]

86. Carrero, I.; Liu, H.-C.; Sikora, A.G.; Milosavljevic, A. Histoepigenetic analysis of HPV- and tobacco-associated head and neck cancer identifies both subtype-specific and common therapeutic targets despite divergent microenvironments. Oncogene 2019, 38, 3551-3568. [CrossRef] [PubMed]

87. Stenner, M.; Yosef, B.; Huebbers, C.U.; Preuss, S.F.; Dienes, H.-P.; Speel, E.-J.M.; Odenthal, M.; Klussmann, J.P. Nuclear translocation of $\beta$-catenin and decreased expression of epithelial cadherin in human papillomavirus-positive tonsillar cancer: An early event in human papillomavirus-related tumour progression?: Nuclear $\beta$-catenin and HPV in OSCC. Histopathology 2011, 58, 1117-1126. [CrossRef]

88. Qian, G.; Hu, Z.; Xu, H.; Müller, S.; Wang, D.; Zhang, H.; Kim, S.; Chen, Z.; Saba, N.F.; Shin, D.M.; et al. A novel prediction model for human papillomavirus-associated oropharyngeal squamous cell carcinoma using p16 and subcellular $\beta$-catenin expression. J. Oral Pathol. Med. 2016, 45, 399-408. [CrossRef]

89. Rampias, T.; Boutati, E.; Pectasides, E.; Sasaki, C.; Kountourakis, P.; Weinberger, P.; Psyrri, A. Activation of Wnt Signaling Pathway by Human Papillomavirus E6 and E7 Oncogenes in HPV16-Positive Oropharyngeal Squamous Carcinoma Cells. Mol. Cancer Res. 2010, 8, 433-443. [CrossRef] 
90. Al Moustafa, A.-E.; Foulkes, W.D.; Benlimame, N.; Wong, A.; Yen, L.; Bergeron, J.; Batist, G.; Alpert, L.; Alaoui-Jamali, M.A. E6/E7 proteins of HPV type 16 and ErbB-2 cooperate to induce neoplastic transformation of primary normal oral epithelial cells. Oncogene 2004, 23, 350-358. [CrossRef]

91. Kanojia, D.; Vaidya, M.M. 4-Nitroquinoline-1-oxide induced experimental oral carcinogenesis. Oral Oncol. 2006, 42, 655-667. [CrossRef] [PubMed]

92. Sato, K.; Okazaki, Y.; Tonogi, M.; Tanaka, Y.; Yamane, G. Expression of $\beta$-catenin in rat oral epithelial dysplasia induced by 4-nitroquinoline 1-oxide. Oral Oncol. 2002, 38, 772-778. [CrossRef]

93. Tamura, I.; Sakaki, T.; Chaqour, B.; Howard, P.S.; Ikeo, T.; Macarak, E.J. Correlation of P-cadherin and $\beta$-catenin expression and phosphorylation with carcinogenesis in rat tongue cancer induced with 4-nitroquinoline 1-oxide. Oral Oncol. 2003, 39, 506-514. [CrossRef]

94. Kawakita, D.; Matsuo, K. Alcohol and head and neck cancer. Cancer Metastasis Rev. 2017, 36, 425-434. [CrossRef]

95. Osei-Sarfo, K.; Tang, X.-H.; Urvalek, A.M.; Scognamiglio, T.; Gudas, L.J. The molecular features of tongue epithelium treated with the carcinogen 4-nitroquinoline-1-oxide and alcohol as a model for HNSCC. Carcinogenesis 2013, 34, 2673-2681. [CrossRef]

96. Vidya Priyadarsini, R.; Senthil Murugan, R.; Nagini, S. Aberrant activation of Wnt/ $\beta$-catenin signaling pathway contributes to the sequential progression of DMBA-induced HBP carcinomas. Oral Oncol. 2012, 48, 33-39. [CrossRef]

97. Lemjabbar-Alaoui, H.; Dasari, V.; Sidhu, S.S.; Mengistab, A.; Finkbeiner, W.; Gallup, M.; Basbaum, C. Wnt and Hedgehog Are Critical Mediators of Cigarette Smoke-Induced Lung Cancer. PLoS ONE 2006, 1, e93. [CrossRef]

98. Dalley, A.J.; Abdul Majeed, A.A.; Pitty, L.P.; Major, A.G.; Farah, C.S. LGR5 expression in oral epithelial dysplasia and oral squamous cell carcinoma. Oral Surg. Oral Med. Oral Pathol. Oral Radiol. 2015, 119, 436-440.e1. [CrossRef]

99. Sun, S.; Liu, S.; Duan, S.Z.; Zhang, L.; Zhou, H.; Hu, Y.; Zhou, X.; Shi, C.; Zhou, R.; Zhang, Z. Targeting the c-Met/FZD8 Signaling Axis Eliminates Patient-Derived Cancer Stem-like Cells in Head and Neck Squamous Carcinomas. Cancer Res. 2014, 74, 7546-7559. [CrossRef]

100. Song, J.; Chang, I.; Chen, Z.; Kang, M.; Wang, C.-Y. Characterization of Side Populations in HNSCC: Highly Invasive, Chemoresistant and Abnormal Wnt Signaling. PLoS ONE 2010, 5, e11456. [CrossRef]

101. Wei, X.; Wang, J.; He, J.; Ma, B.; Chen, J. Biological characteristics of CD133+ cancer stem cells derived from human laryngeal carcinoma cell line. Int. J. Clin. Exp. Med. 2014, 7, 2453-2462. [PubMed]

102. Lee, S.H.; Koo, B.S.; Kim, J.M.; Huang, S.; Rho, Y.S.; Bae, W.J.; Kang, H.J.; Kim, Y.S.; Moon, J.H.; Lim, Y.C. $\mathrm{Wnt} / \beta$-catenin signalling maintains self-renewal and tumourigenicity of head and neck squamous cell carcinoma stem-like cells by activating Oct4. J. Pathol. 2014, 234, 99-107. [CrossRef] [PubMed]

103. Yang, F.; Zeng, Q.; Yu, G.; Li, S.; Wang, C.-Y. Wnt/ $\beta$-catenin signaling inhibits death receptor-mediated apoptosis and promotes invasive growth of HNSCC. Cell. Signal. 2006, 18, 679-687. [CrossRef] [PubMed]

104. Ma, C.; Shi, L.; Huang, Y.; Shen, L.; Peng, H.; Zhu, X.; Zhou, G. Nanoparticle delivery of Wnt-1 siRNA enhances photodynamic therapy by inhibiting epithelial-mesenchymal transition for oral cancer. Biomater. Sci. 2017, 5, 494-501. [CrossRef]

105. Iwai, S.; Yonekawa, A.; Harada, C.; Hamada, M.; Katagiri, W.; Nakazawa, M.; Yura, Y. Involvement of the Wnt- $\beta$-catenin pathway in invasion and migration of oral squamous carcinoma cells. Int. J. Oncol. 2010, 37, 1095-1103. [CrossRef]

106. Yang, J.; Wei, D.; Wang, W.; Shen, B.; Xu, S.; Cao, Y. TRAF4 enhances oral squamous cell carcinoma cell growth, invasion and migration by Wnt- $\beta$-catenin. Signaling pathway. Int. J. Clin. Exp. Pathol. 2015, 8, 11837-11846.

107. Duan, Y.; Fan, M. Lentivirus-mediated gene silencing of beta-catenin inhibits growth of human tongue cancer cells: Beta-catenin silencing in tongue cancer. J. Oral Pathol. Med. 2011, 40, 643-650. [CrossRef]

108. Chang, H.W.; Lee, Y.S.; Nam, H.Y.; Han, M.W.; Kim, H.J.; Moon, S.Y.; Jeon, H.; Park, J.J.; Carey, T.E.; Chang, S.E.; et al. Knockdown of $\beta$-catenin controls both apoptotic and autophagic cell death through LKB1/AMPK signaling in head and neck squamous cell carcinoma cell lines. Cell. Signal. 2013, 25, 839-847. [CrossRef]

109. Rhee, C.-S.; Sen, M.; Lu, D.; Wu, C.; Leoni, L.; Rubin, J.; Corr, M.; Carson, D.A. Wnt and frizzled receptors as potential targets for immunotherapy in head and neck squamous cell carcinomas. Oncogene 2002, 21, 6598-6605. [CrossRef] 
110. Zheng, L.; Li, N.; Guo, F.; Jian, X.-C.; Jiang, C.-H.; Yin, P.; Min, A.-J.; Huang, L. Twist-related protein 1 enhances oral tongue squamous cell carcinoma cell invasion through $\beta$-catenin signaling. Mol. Med. Rep. 2015, 11, 2255-2261. [CrossRef]

111. Way, T.-D.; Huang, J.-T.; Chou, C.-H.; Huang, C.-H.; Yang, M.-H.; Ho, C.-T. Emodin represses TWIST1-induced epithelial-mesenchymal transitions in head and neck squamous cell carcinoma cells by inhibiting the $\beta$-catenin and Akt pathways. Eur. J. Cancer 2014, 50, 366-378. [CrossRef] [PubMed]

112. Wang, L.-P.; Chen, S.-W.; Zhuang, S.-M.; Li, H.; Song, M. Galectin-3 Accelerates the Progression of Oral Tongue Squamous Cell Carcinoma via a Wnt/ $\beta$-catenin-Dependent Pathway. Pathol. Oncol. Res. 2013, 19, 461-474. [CrossRef] [PubMed]

113. Wang, Y.; Yue, D. CUL4B promotes aggressive phenotypes of HNSCC via the activation of the Wnt/ $\beta$-catenin signaling pathway. Cancer Med. 2019, 8, 2278-2287. [CrossRef] [PubMed]

114. Kimura, R.; Kasamatsu, A.; Koyama, T.; Fukumoto, C.; Kouzu, Y.; Higo, M.; Endo-Sakamoto, Y.; Ogawara, K.; Shiiba, M.; Tanzawa, H.; et al. Glutamate acid decarboxylase 1 promotes metastasis of human oral cancer by $\beta$-catenin translocation and MMP7 activation. BMC Cancer 2013, 13, 555. [CrossRef] [PubMed]

115. Zhou, G.; Xie, T.-X.; Zhao, M.; Jasser, S.; Younes, M.; Sano, D.; Lin, J.; Kupferman, M.; Santillan, A.; Patel, V.; et al. Reciprocal negative regulation between S100A7/psoriasin and $\beta$-catenin signaling plays an important role in tumor progression of squamous cell carcinoma of oral cavity. Oncogene 2008, 27, 3527-3538. [CrossRef]

116. Anitha, P.; Priyadarsini, R.V.; Kavitha, K.; Thiyagarajan, P.; Nagini, S. Ellagic acid coordinately attenuates $\mathrm{Wnt} / \beta$-catenin and NF- $\mathrm{kB}$ signaling pathways to induce intrinsic apoptosis in an animal model of oral oncogenesis. Eur. J. Nutr. 2013, 52, 75-84. [CrossRef]

117. Kavitha, K.; Kowshik, J.; Kishore, T.K.K.; Baba, A.B.; Nagini, S. Astaxanthin inhibits NF-кB and Wnt/ $\beta$-catenin signaling pathways via inactivation of Erk/MAPK and PI3K/Akt to induce intrinsic apoptosis in a hamster model of oral cancer. Biochim. Biophys. Acta BBA Gen. Subj. 2013, 1830, 4433-4444. [CrossRef]

118. Yao, C.-J.; Lai, G.-M.; Yeh, C.-T.; Lai, M.-T.; Shih, P.-H.; Chao, W.-J.; Whang-Peng, J.; Chuang, S.-E.; Lai, T.-Y. Honokiol Eliminates Human Oral Cancer Stem-Like Cells Accompanied with Suppression of Wnt/ $\beta$-Catenin Signaling and Apoptosis Induction. Evid. Based Complement. Alternat. Med. 2013, 2013, 1-10. [CrossRef]

119. Srivastava, G.; Matta, A.; Fu, G.; Somasundaram, R.T.; Datti, A.; Walfish, P.G.; Ralhan, R. Anticancer activity of pyrithione zinc in oral cancer cells identified in small molecule screens and xenograft model: Implications for oral cancer therapy. Mol. Oncol. 2015, 9, 1720-1735. [CrossRef]

120. Nayak, A.; Siddharth, S.; Das, S.; Nayak, D.; Sethy, C.; Kundu, C.N. Nanoquinacrine caused apoptosis in oral cancer stem cells by disrupting the interaction between GLI1 and $\beta$-catenin through activation of GSK3 $\beta$. Toxicol. Appl. Pharmacol. 2017, 330, 53-64. [CrossRef]

121. Lim, Y.C.; Kang, H.J.; Kim, Y.S.; Choi, E.C. All-trans-retinoic acid inhibits growth of head and neck cancer stem cells by suppression of Wnt/ $\beta$-catenin pathway. Eur. J. Cancer 2012, 48, 3310-3318. [CrossRef] [PubMed]

122. Kleszcz, R.; Paluszczak, J.; Baer-Dubowska, W. The effect of niclosamide on the head and neck carcinoma cells survival and the expression of $\mathrm{Wnt} / \beta$-catenin signaling and glycolysis pathway components. Acta Pol. Pharm. Drug Res. 2019, 76, 661-669. [CrossRef]

123. Wang, L.-H.; Xu, M.; Fu, L.-Q.; Chen, X.-Y.; Yang, F. The Antihelminthic Niclosamide Inhibits Cancer Stemness, Extracellular Matrix Remodeling, and Metastasis through Dysregulation of the Nuclear $\beta$-catenin/c-Myc axis in OSCC. Sci. Rep. 2018, 8, 12776. [CrossRef] [PubMed]

124. Kleszcz, R.; Szymańska, A.; Krajka-Kuźniak, V.; Baer-Dubowska, W.; Paluszczak, J. Inhibition of CBP/ $\beta$-catenin and porcupine attenuates Wnt signaling and induces apoptosis in head and neck carcinoma cells. Cell. Oncol. 2019, 42, 505-520. [CrossRef] [PubMed]

125. Liu, J.; Pan, S.; Hsieh, M.H.; Ng, N.; Sun, F.; Wang, T.; Kasibhatla, S.; Schuller, A.G.; Li, A.G.; Cheng, D.; et al. Targeting Wnt-driven cancer through the inhibition of Porcupine by LGK974. Proc. Natl. Acad. Sci. USA 2013, 110, 20224-20229. [CrossRef] [PubMed]

126. Zimmerli, D.; Cecconi, V.; Valenta, T.; Hausmann, G.; Cantù, C.; Restivo, G.; Hafner, J.; Basler, K.; van den Broek, M. WNT ligands control initiation and progression of human papillomavirus-driven squamous cell carcinoma. Oncogene 2018, 37, 3753-3762. [CrossRef]

127. Goto, M.; Mitra, R.S.; Liu, M.; Lee, J.; Henson, B.S.; Carey, T.; Bradford, C.; Prince, M.; Wang, C.-Y.; Fearon, E.R.; et al. Rap1 Stabilizes -Catenin and Enhances $\beta$-Catenin-Dependent Transcription and Invasion in Squamous Cell Carcinoma of the Head and Neck. Clin. Cancer Res. 2010, 16, 65-76. [CrossRef] 
128. Sogutlu, F.; Kayabasi, C.; Ozmen Yelken, B.; Asik, A.; Gasimli, R.; Dogan, F.; Yilmaz Süslüer, S.; Biray Avc1, C.; Gunduz, C. The effect of ICRT-3 on Wnt signaling pathway in head and neck cancer. J. Cell. Biochem. 2019, 120, 380-395. [CrossRef]

129. Paluszczak, A.; Kleszcz, R.; Witczak, O.; Krajka-Kuźniak, V. The comparison of the effects of panobinostat and PKF118-310 on $\beta$-catenin-dependent transcription in head and neck squamous cell carcinoma cell lines. Acta Pol. Pharm. Drug Res. 2020, 77, 77-88. [CrossRef]

130. Wend, P.; Fang, L.; Zhu, Q.; Schipper, J.H.; Loddenkemper, C.; Kosel, F.; Brinkmann, V.; Eckert, K.; Hindersin, S.; Holland, J.D.; et al. Wnt/ $\beta$-catenin signalling induces MLL to create epigenetic changes in salivary gland tumours. EMBO J. 2013, 32, 1977-1989. [CrossRef]

131. Kartha, V.K.; Alamoud, K.A.; Sadykov, K.; Nguyen, B.-C.; Laroche, F.; Feng, H.; Lee, J.; Pai, S.I.; Varelas, X.; Egloff, A.M.; et al. Functional and genomic analyses reveal therapeutic potential of targeting $\beta$-catenin/CBP activity in head and neck cancer. Genome Med. 2018, 10, 54. [CrossRef] [PubMed]

132. Zhu, Q.; Fang, L.; Heuberger, J.; Kranz, A.; Schipper, J.; Scheckenbach, K.; Vidal, R.O.; Sunaga-Franze, D.Y.; Müller, M.; Wulf-Goldenberg, A.; et al. The Wnt-Driven Mll1 Epigenome Regulates Salivary Gland and Head and Neck Cancer. Cell Rep. 2019, 26, 415-428.e5. [CrossRef] [PubMed]

133. Peng, C.; Jia, X.; Xiong, Y.; Yin, J.; Li, N.; Deng, Y.; Luo, K.; Zhang, Q.; Wang, C.; Zhang, Z.; et al. The 14-3-3 $/$ /GSK3 $\beta / \beta$-catenin/ZEB1 regulatory loop modulates chemo-sensitivity in human tongue cancer. Oncotarget 2015, 6, 20177-20189. [CrossRef] [PubMed]

134. Li, S.-J.; Yang, X.-N.; Qian, H.-Y. Antitumor effects of WNT2B silencing in GLUT1 overexpressing cisplatin resistant head and neck squamous cell carcinoma. Am. J. Cancer Res. 2014, 5, 300-308.

135. Chang, H.W.; Nam, H.Y.; Kim, H.J.; Moon, S.Y.; Kim, M.R.; Lee, M.; Kim, G.C.; Kim, S.W.; Kim, S.Y. Effect of $\beta$-catenin silencing in overcoming radioresistance of head and neck cancer cells by antagonizing the effects of AMPK on Ku70/Ku80: $\beta$-Catenin Controls Radiation Sensitivity. Head Neck 2016, 38, E1909-E1917. [CrossRef]

136. Chang, H.W.; Roh, J.-L.; Jeong, E.-J.; Lee, S.; Kim, S.-W.; Choi, S.-H.; Park, S.-K.; Kim, S.Y. Wnt signaling controls radiosensitivityvia cyclooxygenase-2-mediated Ku expression in head and neck cancer. Int. J. Cancer 2008, 122, 100-107. [CrossRef]

137. Wang, J.-F.; Liu, C.; Zhang, Q.; Huang, G.-H. Research progress in the radioprotective effect of the canonical Wnt pathway. Cancer Biol. Med. 2013, 10, 61-71.

(C) 2020 by the author. Licensee MDPI, Basel, Switzerland. This article is an open access article distributed under the terms and conditions of the Creative Commons Attribution (CC BY) license (http://creativecommons.org/licenses/by/4.0/). 